\title{
Article \\ HPLC-DAD Based Polyphenolic Profiling and Evaluation of Pharmacological Attributes of Putranjiva roxburghii Wall.
}

\author{
Adila Nazli ${ }^{1,2}{ }^{(}$, Muhammad Zafar Irshad Khan ${ }^{3}$, Madiha Ahmed ${ }^{4, *}$, Nosheen Akhtar ${ }^{5}{ }^{(}$, Mohammad K. Okla ${ }^{6}$, \\ Abdulrahman Al-Hashimi ${ }^{6}$, Wahidah H. Al-Qahtani ${ }^{7}$, Hamada Abdelgawad ${ }^{8}$ and Ihsan-ul- Haq ${ }^{1, *}$ \\ 1 Department of Pharmacy, Faculty of Biological Sciences, Quaid-i-Azam University, Islamabad 45320, Pakistan; \\ adilanazli44@gmail.com \\ 2 Chongqing Key Laboratory of Natural Product Synthesis and Drug Research, School of Pharmaceutical \\ Sciences, Chongqing University, Chongqing 401331, China \\ 3 College of Pharmaceutical Sciences, Zhejiang University, Hangzhou 310058, China; m.zafarirshad@yahoo.com \\ 4 Shifa College of Pharmaceutical Sciences, Shifa Tameer-e-Millat University, Islamabad 44000, Pakistan \\ 5 Department of Biological Sciences, National University of Medical Sciences, Rawalpindi 43600, Pakistan; \\ nosheenakhtar@numspak.edu.pk \\ 6 Botany and Microbiology Department, College of Science, King Saud University, Riyadh 11451, Saudi Arabia; \\ okla103@yahoo.com (M.K.O.); al-ghamd@gmail.com (A.A.-H.) \\ 7 Department of Food Sciences \& Nutrition, College of Food \& Agriculture Sciences, King Saud University, \\ Riyadh 11451, Saudi Arabia; wahida@ksu.edu.sa \\ 8 Integrated Molecular Plant Physiology Research, Department of Biology, University of Antwerp, \\ 2020 Antwerpen, Belgium; hamada.abdelgawad@uantwerpen.be \\ * Correspondence: madiha.scps@stmu.edu.pk (M.A.); ihaq@qau.edu.pk (I.-u.-H.)
}

Citation: Nazli, A.; Irshad Khan, M.Z.; Ahmed, M.; Akhtar, N.; Okla, M.K.; Al-Hashimi, A.; Al-Qahtani, W.H.; Abdelgawad, H.; Haq, I.-u.HPLC-DAD Based Polyphenolic Profiling and Evaluation of Pharmacological Attributes of Putranjiva roxburghii Wall.. Molecules 2022, 27, 68. https://doi.org/ $10.3390 /$ molecules 27010068

Academic Editors: Ana Paula Duarte, Eugenia Gallardo and Ângelo Luís

Received: 9 November 2021

Accepted: 18 December 2021

Published: 23 December 2021

Publisher's Note: MDPI stays neutral with regard to jurisdictional claims in published maps and institutional affiliations.

Copyright: (C) 2021 by the authors. Licensee MDPI, Basel, Switzerland. This article is an open access article distributed under the terms and conditions of the Creative Commons Attribution (CC BY) license (https:// creativecommons.org/licenses/by/ $4.0 /)$.

\begin{abstract}
The current study was intended to explore the phytochemical profiling and therapeutic activities of Putranjiva roxburghii Wall. Crude extracts of different plant parts were subjected to the determination of antioxidant, antimicrobial, antidiabetic, cytotoxic, and protein kinase inhibitory potential by using solvents of varying polarity ranges. Maximum phenolic content was notified in distilled water extracts of the stem (DW-S) and leaf (DW-L) while the highest flavonoid content was obtained in ethyl acetate leaf (EA-L) extract. HPLC-DAD analysis confirmed the presence of various polyphenols, quantified in the range of $0.02 \pm 0.36$ to $2.05 \pm 0.18 \mu \mathrm{g} / \mathrm{mg}$ extract. Maximum DPPH scavenging activity was expressed by methanolic extract of the stem (MeOH-S). The highest antioxidant capacity and reducing power was shown by MeOH-S and leaf methanolic extract $(\mathrm{MeOH}-$ L), respectively. Proficient antibacterial activity was shown by EA-L extract against Bacillus subtilis and Escherichia coli. Remarkable $\alpha$-amylase and $\alpha$-glucosidase inhibition potential was expressed by ethyl acetate fruit (EA-F) and n-Hexane leaf (nH-L) extracts, respectively. In case of brine shrimp lethality assay, $41.67 \%$ of the extracts ( $\mathrm{LC}_{50}<50 \mu \mathrm{g} / \mathrm{mL}$ ) were considered as extremely cytotoxic. The test extracts also showed mild antifungal and protein kinase inhibition activities. The present study explores the therapeutic potential of $P$. roxburghii and calls for subsequent studies to isolate new bioactive leads through bioactivity-guided isolation.
\end{abstract}

Keywords: natural products; phenolic compounds; brine shrimps; protein kinase inhibition; antioxidants

\section{Introduction}

Plants are nature's gifts that have been employed for the management of various healththreatening diseases since the early ages [1-3]. It has been revealed that approximately $80 \%$ of the population across the globe depends upon plant-based therapeutics for healthcare needs [3]. Phytoconstituents are the compounds generated by plants as a defense system against pathogens and predators. They possess certain characteristics that are helpful for the treatment of diseases including antimicrobial, antioxidant, and stimulation as well as inhibition enzymes [4]. Plants contain a wide range of constituents such as alkaloids, tannins, polyphenolics, terpenoids, etc. which are attributable to therapeutic potential [5]. Phytochemicals either isolated compounds or crude extracts, providing opportunity for 
drug discovery. Human beings seem interested in natural therapeutics as synthetic drugs are associated with adverse effects [6]. Plant-based therapeutic agents are cost-effective and possess fewer side effects as compared to synthetic agents [2].

The current era has noticed the growing enthusiasm of pharmaceutical industries to explore plants for the discovery of new therapeutic moieties [7]. Various commercially available therapeutic agents have been derived from plants such as galegine isolated from Galega officinalis L. provided the base for synthesis of metformin which is an antidiabetic drug. Cinchona obtained from Cinchona officinalis lead to the development of chloroquine and mefloquine as antimalarial agents [8]. Moreover, vinblastine, vincristine isolated from Vinca rosea Linn., and paclitaxel derived from Taxus brevifolia are currently available anticancer agents $[9,10]$.

Currently, HPLC is acquiring popularity for the identification of phytochemicals. Qualitative analysis generates a "fingerprint" chromatogram which is helpful for quality control of phytoconstituents. We can also use TLC; however, under certain circumstances it can give false results. HPLC is also helpful for chemosystematics and capable to characterize different species on the basis of their secondary metabolite contents. Reversed-phase HPLC is being widely used for analysis of flavonoids [11].

Putranjiva roxburghii Wall. is a moderate size, evergreen tree from the Euphorbiaceae family. It is mainly found in Thailand, Myanmar, Sri Lanka, Bangladesh, Nepal, and Indochina [12,13]. Folklore uses of $P$. roxburghii include treatment of rheumatism, muscle twisting, fever, arthralgia, pain, and inflammation [14,15]. Previous studies have revealed the presence of a wide range of triterpenoids including putranjivadione, putranjivanonol, putranjic acid, roxburghonic acid, and roxburgholone, etc. [16-19]. Despite the traditional use of $P$. roxburghii since ancient times for various ailments; scientific evidence regarding the therapeutic potential of this plant and phytochemical profiling is still deficient [16]. Reliability for the therapeutic potential of conventionally used plants requires scientifically valid data. Therefore, the therapeutic effectiveness of plants should be explored to provide a base for the isolation of bioactive leads thus facilitating the drug discovery process [20]. Lack of data on polyphenolic profiling and absence of scientific evidence for the therapeutic potential of $P$. roxburghii encouraged us to bridge this research gap. Hence, the present study was carried out to analyze the polyphenols present in different parts of $P$. roxburghii and to evaluate their potential implications for reducing oxidative stress. Moreover, the antibacterial, antifungal, $\alpha$-amylase inhibition, $\alpha$-glucosidase inhibition, protein-kinase inhibition, and cytotoxic potential of these extracts were also explored.

\section{Materials and Methods}

\subsection{Acquisition and Identification of Selected Plants}

Different plant parts (stems, leaves, and fruits) were acquired from the locality of Quaid-i-Azam University, Islamabad $\left(33.747^{\circ} \mathrm{N}, 73.1356^{\circ} \mathrm{E}\right)$ in December 2018. After identification, an authorized sample of the plant was kept in the departmental Herbarium, under voucher number PHM $510 \mathrm{~mL}$.

\subsection{Reagents and Solvents for Biological Evaluation}

PhosPhate buffer was acquired from Riedel-de Haen, Seelze, Germany while Sabouraud dextrose agar from Oxoid, England. Ferric chloride, Potassium ferricyanide, Trichloroacetic acid (TCA), Tryptone soy broth, Surfactin, Doxorubicin, Ascorbic acid, 2,2-diphenyl-1-picrylhydrazyl (DPPH), Nutrient agar, Sea salt, Standard antifungals (clotrimazole and amphotericin B) and Standard antibiotics (cefixime and roxithromycin) were purchased from Sigma Aldrich, Saint Louis, MO, USA. Dried instant yeast was acquired from Fermipan BDH, Poole, England and Medium ISP4 was formulated in laboratory. Brine shrimp "Artemia salina" eggs were acquired from Ocean star Int., Coral springs, FL, USA and Tween-20 from Merck-Schuchardt, USA. Microplate reader was purchased from Biotech, Minneapolis, MN, USA, microplate reader Elx 800 while Eppendorf tubes were acquired from Merck, Kenilworth, NJ, USA. Bacterial and fungal 
strains were acquired from (Microbiologics, Saint Cloud, MN, USA). Eppendorf tubes were taken from Merck, Kenilworth, NJ, USA.

\subsection{Preparation of Crude Extracts}

Plant parts were thoroughly washed and shade-dried for four weeks. After drying, plant parts were crumbled and subjected to the sonication aided maceration in $1000 \mathrm{~mL}$ Erlenmeyer flasks for three days. Solvents used for maceration include n-hexane $(\mathrm{nH})$, ethyl acetate (EA), methanol (MeOH), and distilled water (DW), respectively. After the specified duration, filtration was done while marc was macerated in the same solvent for 1 day followed by filtration. All filtrates of the same solvent were merged and subjected to drying by a rotary evaporator (Buchi, Flawil, Switzerland). The crude extracts after complete drying were stored at $-80^{\circ} \mathrm{C}$.

Following formula was used to calculate percent extract recovery:

$$
\text { Percent extract recovery }(\% w / w)=(\mathrm{x} / \mathrm{y}) \times 100
$$

$\mathrm{x}=$ Total weight of the dried extract, $\mathrm{y}=$ Total dried weight of the powdered plant material used in extraction, i.e., $500 \mathrm{~g}$ each part.

\subsection{Phytochemical Analysis}

Stock solutions of all test extracts were formulated as $4 \mathrm{mg} / \mathrm{mL}$ DMSO for phytochemical analysis.

\subsubsection{Determination of Total Phenolic Content (TPC)}

Initially, $20 \mu \mathrm{L}$ test extract was shifted to the different wells of 96-well plate with subsequent inclusion of $90 \mu \mathrm{L}$ Folin-Ciocalteu (FC reagent), $90 \mu \mathrm{L}$ of sodium carbonate and absorbance was checked after incubation. Gallic acid was taken as positive control and calibration curve was plotted $(\mathrm{y}=0.0738 \mathrm{x}+0.086)$ while DMSO was taken as negative control. Results were depicted as the mean of $\mu$ g gallic acid equivalent (GAE) /mg extract \pm SD [21]

\subsubsection{Determination of Total Flavonoid Content (TFC)}

Initially, $20 \mu \mathrm{L}$ test extract was shifted to different wells of the 96-well plate with subsequent inclusion of $10 \mu \mathrm{L}(1 \mathrm{M})$ potassium acetate solution, $10 \mu \mathrm{L}(10 \%)$ aluminum chloride, and $160 \mu \mathrm{L}$ distilled water and absorbance was checked after incubation. Quercetin was taken as a positive control and the calibration curve was plotted $(\mathrm{y}=0.0535 \mathrm{x}-0.0033)$ while DMSO was employed as negative control. Results were recorded as mean of $\mu \mathrm{g}$ quercetin equivalent $(\mathrm{QE}) / \mathrm{mg}$ extract $\pm \mathrm{SD}[21]$.

\subsubsection{HPLC-DAD Analysis}

High performance liquid chromatography (HPLC) was carried out by Agilent Chem station Rev. B.02-01-SR1 (260), Boulder, Colorado, USA [22]. Two mobile phases were employed including acetonitrile-methanol-water-acetic acid in a ratio of 5:10:85:1 (solvent A) and acetonitrile-methanol-acetic acid in a ratio of 40:60:1 (solvent B). Stock solutions of different polyphenols including cinnamic acid derivatives (caffeic acid, ferulic acid, coumaric acid), benzoic acid derivative (vanillic acid, gallic acid, syringic acid, gentisic acid), flavanol flavonoids (kaempferol, quercetin, myricitin), flavan-3-ol flavonoids (catechin), flavone flavonoid (luteolin, apigenin), naphthoquinone (plumbagin), anthraquinone (emodin), and benzoquinone (thymoquinone). Serial dilutions of stock solutions were prepared, i.e., $10,20,50,100,200 \mu \mathrm{g} / \mathrm{mL}$, and a calibration curve was plotted for peak areas at different concentrations of standards. The absorption of samples was checked at $257 \mathrm{~nm}$, $279 \mathrm{~nm}, 325 \mathrm{~nm}$, and $368 \mathrm{~nm}$ and the results were depicted as $\mu \mathrm{g} / \mathrm{mg}$ extract. Polyphenols were identified by comparing the retention time of test samples with standards and results were expressed as mean of polyphenolic concentration $\mu \mathrm{g} / \mathrm{mg} \pm$ S.D. 


\subsubsection{Reagents and Solvents for Phytochemical Analysis}

Ethyl acetate, Methanol, Dimethyl sulfoxide (DMSO), and n-hexane were purchased from Sigma-Aldrich, Schnelldorf, Germany. Folin-Ciocalteu (FC) reagent was acquired from Riedel-de Haen, Germany. Quercetin, Potassium acetate, Gallic acid, and Aluminium chloride were purchased from Sigma Aldrich, Saint Louis, MO, USA. Rotary evaporator was acquired from Buchi, Flawil, Switzerl and while microplate reader was purchased from Biotech USA, microplate reader Elx 800. HPLC was acquired from Agilent Chem station Rev. B.02-01-SR1 (260), Boulder, Colorado, USA. Eppendorf tubes were taken from Merck, Kenilworth, NJ, USA.

\subsection{Biological Evaluation}

\subsubsection{Antioxidant Assays}

DPPH Free Radical Scavenging Assay

At first, each test extract $(10 \mu \mathrm{L})$ was shifted to the corresponding wells of a 96 wellplate with subsequent inclusion of $190 \mu \mathrm{L}$ DPPH solution and [23]. The absorbance was checked and \% scavenging activity was determined as:

$$
\% \text { Scavenging activity }=(1-\mathrm{Abs} / \mathrm{Abc}) \times 100
$$

whereas $\mathrm{Abs}=$ Absorbance of sample, $\mathrm{Abc}=$ Absorbance of control. Ascorbic acid and DMSO were employed as positive and negative controls, respectively. Results were expressed as the mean of \% DPPH scavenging activity \pm SD and $\mathrm{IC}_{50}$ value was determined for the samples expressing more than $50 \%$ scavenging activity.

\section{Determination of Total Antioxidant Capacity (TAC)}

Initially, each test sample $(100 \mu \mathrm{L})$ was shifted to Eppendorf tubes with subsequent addition of $900 \mu \mathrm{L}$ TAC reagent and incubation at $95^{\circ} \mathrm{C}$ for $90 \mathrm{~min}$ [24]. Ascorbic acid and DMSO were taken as positive control and blank, respectively. Absorbance of the reaction mixture was noted at $630 \mathrm{~nm}$ and a calibration curve was plotted $(\mathrm{y}=0.0408 \mathrm{x}-0.025)$ while results were illustrated as the mean of $\mu \mathrm{g}$ ascorbic acid equivalent (AAE)/mg extract \pm SD.

\section{Determination of Total Reducing Power (TRP)}

TRP of test extracts was investigated by adopting a previously reported protocol [24]. At first, each test extract $(100 \mu \mathrm{L})$ was shifted to Eppendorf tubes (Merck, Kenilworth, USA) with the subsequent addition of $200 \mu \mathrm{L}$ phosphate buffer $(0.2 \mathrm{~mol} / \mathrm{L}, \mathrm{pH} 6.6)$ and $250 \mu \mathrm{L}$ of $1 \%$ potassium ferricyanide. Amalgam was incubated and $10 \%$ trichloroacetic acid $(200 \mu \mathrm{L})$ was then added followed by centrifugation. Then, $150 \mu \mathrm{L}$ aliquots from the supernatant was transferred into the wells of microtiter plate containing $\mathrm{FeCl}_{3}(50 \mu \mathrm{L}$, $0.1 \%$ ) and absorbance was recorded. Positive and negative controls were ascorbic acid and DMSO. A calibration curve was plotted $(y=0.0754 x+0.1034)$ while the results were demonstrated as a mean of $\mu \mathrm{g} \mathrm{AAE} / \mathrm{mg}$ extract \pm S.D.

\subsubsection{Antimicrobial Assays \\ Antibacterial Assay}

The antibacterial activity of test samples was investigated by disc diffusion protocol [25]. Refreshed bacterial cultures [Pseudomonas aeruginosa (ATCC15442), Staphylococcus aureus (ATCC-6538), Klebsiella pneumoniae (ATCC-1705), Escherichia coli (ATCC-25922), and Bacillus subtilis (ATCC-6633)] (Microbiologics, Saint Cloud, MN, USA) were employed to prepare lawns on nutrient agar plates. Briefly, $5 \mu \mathrm{L}$ aliquots of every sample were transferred from stock solution ( $20 \mathrm{mg} / \mathrm{mL}$ DMSO) to discs. Subsequently, cefixime and roxithromycin were chosen as positive control while DMSO as a negative control. The discs were implanted on agar plates followed by incubation and zones of inhibition (ZOI) were measured $(\mathrm{mm})$ around each disc. Minimum inhibitory concentration (MIC) was investigated for all the test samples showing $\geq 12 \mathrm{~mm}$ zone of inhibition. For MIC determi- 
nation, the bacterial inoculum was prepared with a pre-defined density $\left(5 \times 10^{4} \mathrm{CFU} / \mathrm{mL}\right)$. Serial dilutions were prepared for each test sample in a 96-well plate by using nutrient broth. Subsequently, $195 \mu \mathrm{L}$ of inoculum was included and the plate was then incubated. The absorbance of assay plate was recorded after $30 \mathrm{~min}$ (zero time reading) and $24 \mathrm{~h}$ of incubation and difference was determined. Percent inhibition of bacterial growth was calculated as:

$$
\% \text { inhibition }=\left(1-\mathrm{T}_{\mathrm{s}} / \mathrm{T}_{\mathrm{c}}\right) \times 100
$$

$\mathrm{T}_{\mathrm{S}}$ is the turbidity of the sample well and $\mathrm{T}_{\mathrm{C}}$ is the turbidity of the control well. The lowest concentration at which test samples showed $\geq 90 \%$ inhibition of bacterial growth was referred as MIC.

\section{Antifungal Assay}

Initially, refreshed inoculum was prepared by harvesting the fungal strains, i.e., Mucor species (FCBP 0300), Aspergillus niger (FCBP 0198), Aspergillus flavus (FCBP 0064), Fusarium solani (FCBP 0291), and Aspergillus fumigatus (FCBP 66) (Microbiologics, Saint Cloud, MN, USA) in Tween 20 solution. Subsequently, 20-25 mL sabouraud dextrose agar (SDA) was taken in petri plates and swabbed with refreshed inoculum $(100 \mu \mathrm{L})$. The discs loaded with test extracts ( $5 \mu \mathrm{L}, 20 \mathrm{mg} / \mathrm{mL}$ DMSO), clotrimazole $(5 \mu \mathrm{L}, 4 \mathrm{mg} / \mathrm{mL}$ DMSO) and DMSO $(5 \mu \mathrm{L})$ were implanted on SDA plates. The petri plates were then incubated and ZOI $(\mathrm{mm})$ around each disc was measured after incubation [26].

\subsubsection{Enzyme Inhibition Assays}

$\alpha$-Amylase Inhibition Assay

This assay was conducted in accordance with a preceding protocol [24]. First of all, phosphate buffer $(15 \mu \mathrm{L}, \mathrm{pH} 6.8)$, $\alpha$-amylase enzyme $(25 \mu \mathrm{L}, 0.0175 \mathrm{U} / \mathrm{mL})$, test sample $(10 \mu \mathrm{L}, 4 \mathrm{mg} / \mathrm{mL}$ DMSO) and starch solution $(40 \mu \mathrm{L}, 2 \mathrm{mg} / \mathrm{mL}$ potassium phosphate buffer) were transferred to the corresponding wells of 96 well plate. The plates were kept at $50{ }^{\circ} \mathrm{C}$ for 30 min after which $\mathrm{HCl}(20 \mu \mathrm{L}, 1 \mathrm{M})$ and iodine reagent $(90 \mu \mathrm{L})$ were added, and absorbance was checked at $540 \mathrm{~nm}$. An identical protocol was adopted for the formation of negative and positive controls by substituting the test sample with a similar volume of DMSO and acarbose, respectively. Moreover, a blank was prepared by adding an equal quantity of buffer rather than test extract and $\alpha$-amylase enzyme solution. \%enzyme inhibition was calculated as:

$$
\text { \%enzyme inhibition }=[(\mathrm{Abs}-\mathrm{Abn}) /(\mathrm{Abb}-\mathrm{Abn}) \times 100]
$$

where, $\mathrm{Abs}=$ absorbance of test sample, $\mathrm{Abb}=$ absorbance of blank, and Abn = absorbance of negative control.

\section{$\alpha$-Glucosidase Inhibition Assay}

This assay was executed by adopting a protocol demonstrated by Nair et al. [27]. Initially, a substrate solution $(25 \mu \mathrm{L}, 20 \mathrm{mM})$, phosphate buffer $(69 \mu \mathrm{L}, 50 \mathrm{mM}, \mathrm{pH} 6.8)$, test sample ( $5 \mu \mathrm{L}, 4 \mathrm{mg} / \mathrm{mL} \mathrm{DMSO})$, and enzyme solution $(1 \mu \mathrm{L})$ were transferred to the corresponding wells of 96 well plate. First reading was taken at $405 \mathrm{~nm}$ immediately and the amalgam was placed at $37{ }^{\circ} \mathrm{C}$ for $30 \mathrm{~min}$. The reaction was quenched by sodium bicarbonate solution $(100 \mu \mathrm{L}, 0.5 \mathrm{mM})$ and the absorbance was again checked. Negative and positive controls were prepared by following a similar protocol just by substituting the test extract with the same amount of DMSO and acarbose, respectively. Following formula was used for the calculation of \%enzyme inhibition:

$$
\text { \%enzyme inhibition }=\text { Ac }- \text { As } / \text { Ac } \times 100
$$

Ac $=$ Absorbance of control, As $=$ Absorbance of sample 


\subsubsection{Preliminary Toxicity Test}

Brine Shrimp Lethality Assay

This assay was executed by using brine shrimp (Artemia salina acquired from Ocean star Int., Coral Springs, FL, USA) larvae in a 96 well plate by following a preceding protocol [22]. Artemia salina eggs were allowed to hatch in a dual-chamber punctured tank containing simulated seawater. The chamber filled with eggs was enfolded with aluminum foil while another chamber was kept under a light source. The tank was kept at $30-32{ }^{\circ} \mathrm{C}$ for $24-48 \mathrm{~h}$ after which nauplii started moving towards the lightened chamber. Subsequently, 10 mature nauplii were taken in each well of a 96-well plate with subsequent inclusion of $150 \mu \mathrm{L}$ seawater and corresponding volume of test samples to attain final concentrations of 200,100 , and $50 \mu \mathrm{g} / \mathrm{mL}$. Seawater was added to make the final volume of each well up to $300 \mu \mathrm{L}$. Doxorubicin was chosen as positive control while $1 \%$ DMSO as negative control. Ultimately, 96 well plate was incubated after which dead nauplii were computed by using an inverted microscope. Following formula was used to calculate \%mortality and $\mathrm{LC}_{50}$ was calculated by graph pad prism 5 software (GraphPad, San Diego, CA, USA).

$$
\% \text { mortality }=\text { no. of dead shrimps } / \text { total no. of shrimps } \times 100
$$

\section{Protein Kinase Inhibition Assay}

Mycelia fragments of Streptomyces species were immersed into sterile tryptone soy broth and kept for $24 \mathrm{~h}$. Petri plates containing ISP4 medium were swabbed with refreshed culture $(100 \mu \mathrm{L})$. Subsequently, discs loaded with a test sample $(5 \mu \mathrm{L}, 20 \mathrm{mg} / \mathrm{mL}$ DMSO) were implanted on seeded plates. Surfactin and DMSO-loaded discs were employed as positive and negative controls, respectively. The plates were incubated and the diameter of the bald or clear zone $(\mathrm{mm})$ of inhibition was measured as an indicator of protein kinase inhibition potential [26].

\subsection{Data Analysis}

All the assays were conducted in a triplicate manner and the data have been demonstrated as mean \pm standard deviation of triplicate analysis. $\mathrm{LC}_{50}$ and $\mathrm{IC}_{50}$ values were determined through Graph pad prism 5 software (GraphPad, San Diego, CA, USA) while Post Hoc Tukey HSD (Honest significant difference) test was used to analyze the results using the statistical package SPSS (IBM SPSS, Armonk, NY, USA) and $p<0.05$ (95\% confidence interval) was considered as significant. Correlation coefficient $\left(R^{2}\right)$ of phytochemical activities was calculated by employing the correlation and regression function of Microsoft Excel program (Microsoft, Redmond, WA, USA).

\section{Results and Discussion}

\subsection{Percent Extract Yield}

Percent recovery of test extracts is summarized in Figure 1. The results demonstrated that $\mathrm{DW}$ and $\mathrm{MeOH}$ extracts of leaf possess maximum extraction efficiency, i.e., $6.3 \pm 0.4 \%$ and $5.3 \pm 0.3 \%$, respectively $[28,29]$. During the current study, polar solvents showed maximum extraction efficiency. Water-soluble phytoconstituents mainly present in plants include flavonoids, tannins, terpenoids, quinones, etc. [30,31]. The presence of some of these metabolites might be attributable to the maximum extraction efficiency of DW and $\mathrm{MeOH}$ leaf extracts. The results were in conformity with a previous study in which nonpolar extracts of Ajuga bracteosa Wall. showed less extraction efficiency as compared to polar ones [25]. 


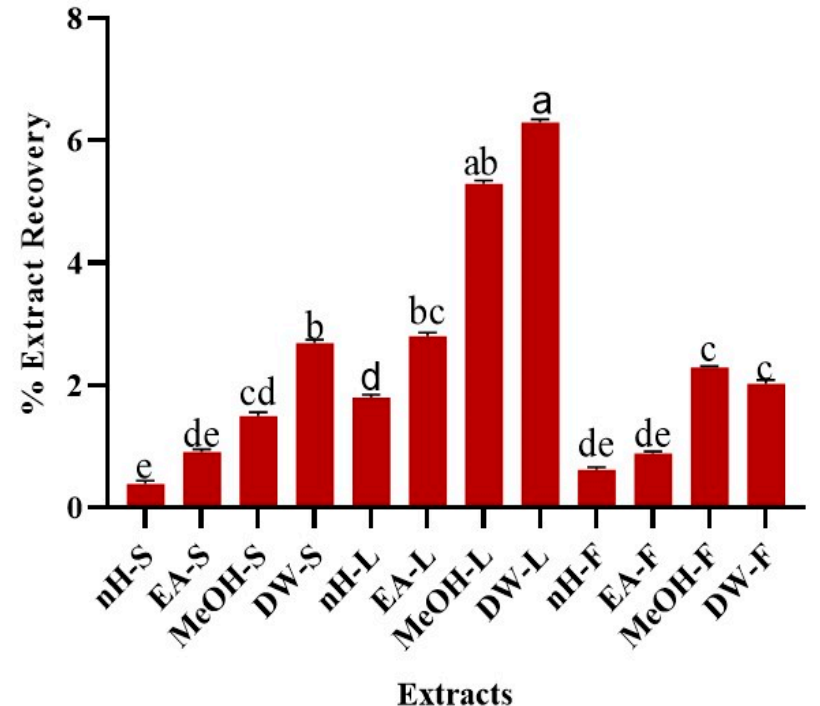

(a)

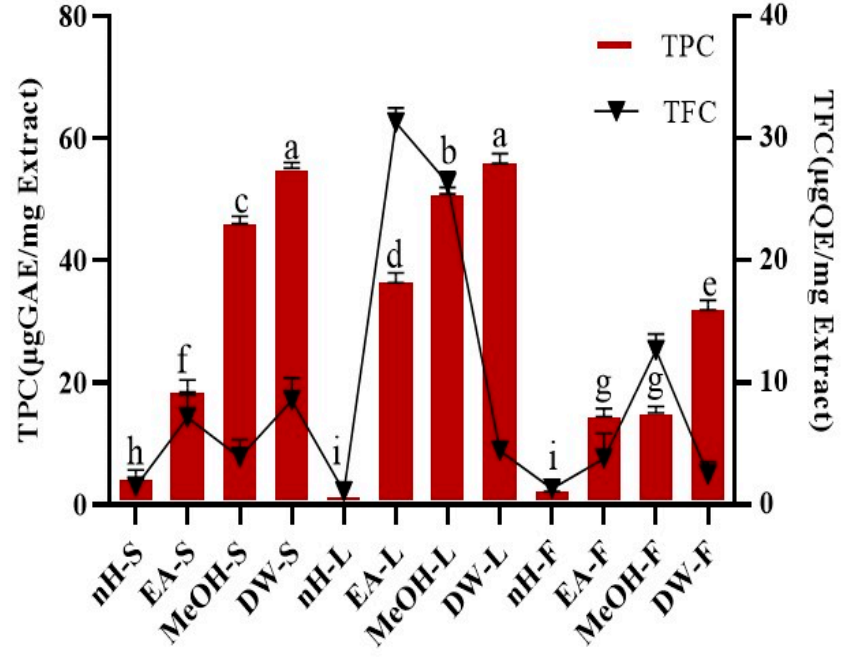

Extracts

(b)

Figure 1. (a) Extraction efficiency, (b) TPC (Total phenolic content $\mu \mathrm{g}$ GAE/mg) and TFC (Total flavonoid content $\mu \mathrm{g} \mathrm{QE} / \mathrm{mg}$ ) of P. roxburghii crude extracts. Assays were conducted in a triplicate manner and the data have been demonstrated as mean \pm standard deviation. Significantly different means $(p<0.05)$ are represented by different superscripts $\left({ }^{\mathrm{a}-\mathrm{i}}\right)$. nH-S; n-Hexane stem, EA-S; ethyl acetate stem, MeOH-S; methanol stem, DW-S; distilled water stem, nH-L; n-Hexane leaf, EA-L; ethyl acetate leaf, $\mathrm{MeOH}-\mathrm{L}$; methanol leaf, DW-L; distilled water leaf, nH-F; n-Hexane fruit, EA-F; ethyl acetate fruit, $\mathrm{MeOH}-\mathrm{F}$; methanol fruit, DW-F; distilled water fruit.

\subsection{Phytochemical Analysis}

\subsubsection{Total Phenolic Content (TPC)}

A remarkable TPC was noted in test extracts. Maximum TPC was notified in DW extracts of stem and leaf, i.e., $55.23 \pm 0.10 \mu \mathrm{g} \mathrm{GAE} / \mathrm{mg}$ extract while least TPC was found in $\mathrm{nH}$ extracts of leaf and fruit, i.e., $2.06 \pm 0.03 \mu \mathrm{g}$ GAE $/ \mathrm{mg}$ extract, respectively (Figure 1). TPC notified in our research was somewhat higher than a recently published study which revealed that $P$. roxburghii leaf (hydroethanol, 30:70) extract contains $46.58 \pm 2.52 \mathrm{mg} / \mathrm{g}$ GAE polyphenolic content [32]. Alterations in agro-climatic conditions accompanied with temperature and rainfall impart a significant impact on the amount of phytoconstituents within similar species of plants growing in different regions [33]. Hence, differences in solvent composition and plant collection sites might be responsible for the variations of estimated TPC in both studies. Current study investigated the phenolic content in fruit and stem parts of P. roxburghii as well and employed a wide range of solvents [32]. Phenolics are secondary metabolites of plants which help to counteract different pathogenic microbes and impart colors to the plants. They are widely distributed in all plant parts and hence, act as an essential component of the human diet [34]. Phenolics are highly effective to counteract oxidative stress-related ailments such as neurodegenerative diseases, cancer, diabetes, ageing, and cardiovascular diseases [35]. Phenolic compounds perform antioxidant activity by the virtue of hydrogen donating action and chelation of metal ions involved in the generation of free radicals $[36,37]$. The presence of hydrophobic benzenoid rings enables the phenolic constituents to interact with proteins and to inhibit enzymes involved in free radical production [36,38]. These compounds can also act as neuroprotective, gastroprotective, antipyreticm, antiatherosclerotic, cardioprotective, antiulcer [39], anti-inflammatory [35], antibacterial [40], antifungal [41], antiviral [42], and antitumor agents [35,43], antidiabetic, anxiolytic [39]. Hence, the presence of a remarkable quantity of phenolic content in P. roxburghii might be accountable to its promising therapeutic potential. 


\subsubsection{Total Flavonoid Content (TFC)}

A significant TFC was observed in crude extracts. Highest TFC was found in EA and $\mathrm{MeOH}$ extracts of leaf, i.e., $30.62 \pm 0.31,27.25 \pm 0.05 \mu \mathrm{g} \mathrm{QE} / \mathrm{mg}$ extract, respectively (Figure 1). Minimum TFC was notified in $\mathrm{nH}$ extracts of stem, leaf, and fruit, i.e., $1.04 \pm 0.02 \mu \mathrm{g} \mathrm{QE} / \mathrm{mg}$ extract. The results were in close resemblance to a previous study which revealed that the hydroethanolic extract of $P$. roxburghii leaf part contains $29.0 \pm 2 \mathrm{mg} / \mathrm{g}$ QE flavonoid content [32]. It was found that EA leaf extract contains a greater quantity of flavonoids than $\mathrm{MeOH}$ extract. Flavonoids are an important class of polyphenolics containing benzo- $\gamma$-pyrone moiety and possess a wide range of therapeutic activities [44]. Flavonoids contain a flavan core, consisting of 15 carbon atoms organized in three rings. Depending upon the oxidation state of the central core, flavonoids are categorized as: anthocyanins, flavanones, isoflavones, flavones, flavanols, and flavonols. The structural differences in each subclass are due to the extent and pattern of prenylation, methoxylation, glycosylation, and hydroxylation [34]. Flavonoids can act as antimicrobial, anti-inflammatory, immunomodulatory, enzyme inhibitor, antiviral, antiparasitic, cardioprotective, cytotoxic, anti-tumor, antiaging agents [45,46]. A wide range of flavonoids have been isolated from roxburghii species such as catechin and quercetin in Rosa roxburghii Tratt. [47], isorhamnetin, rhamnazin, roxburoside from Anoectochilus roxburghii Wall. [48], and putraflavone from P. roxburghii [49]. During the present study, the flavonoid presence in polar extracts of $P$. roxburghii referred it to be a potential reservoir of antioxidants.

\subsubsection{HPLC-DAD Analysis of Polyphenols}

Polyphenols were quantified in various extracts of P. roxburghii by HPLC-DAD analysis (using 16 references) (Figure 2). Caffeic Acid, ferulic acid, coumaric acid, vanillic acid, gallic acid, syringic acid, gentisic acid, catechin, and emodin were present in significant amounts (Table 1). Whereas kaempferol, quercetin, myricitin, luteolin, apigenin, plumbagin, and thymoquinone were not present in any crude extract. Maximum number of polyphenols was detected in DW-L extract including caffeic acid $(0.35 \pm 0.06 \mu \mathrm{g} / \mathrm{mg}$ extract), ferulic acid $(1.02 \pm 0.51 \mu \mathrm{g} / \mathrm{mg}$ extract), vanillic acid $(0.26 \pm 0.32 \mu \mathrm{g} / \mathrm{mg}$ extract), syringic acid $(0.92 \pm 0.52 \mu \mathrm{g} / \mathrm{mg}$ extract), gentisic acid $(1.19 \pm 0.09 \mu \mathrm{g} / \mathrm{mg}$ extract), and catechin $(2.05 \pm 0.18 \mu \mathrm{g} / \mathrm{mg}$ extract). It was followed by EA-F extract which contains coumaric acid $(0.02 \pm 0.36 \mu \mathrm{g} / \mathrm{mg}$ extract $)$, syringic acid $(0.76 \pm 0.42 \mu \mathrm{g} / \mathrm{mg}$ extract), catechin $(0.56 \pm 0.56 \mu \mathrm{g} / \mathrm{mg}$ extract $)$, and emodin $(0.87 \pm 23 \mu \mathrm{g} / \mathrm{mg}$ extract). Subsequently, $\mathrm{MeOH}-\mathrm{F}$ extract contains ferulic acid $(0.44 \pm 0.26 \mu \mathrm{g} / \mathrm{mg}$ extract) and catechin $(0.61 \pm 0.67 \mu \mathrm{g} / \mathrm{mg}$ extract), DW-S extract contains caffeic acid $(0.26 \pm 0.03 \mu \mathrm{g} / \mathrm{mg}$ extract) and catechin $(0.69 \pm 0.18 \mu \mathrm{g} / \mathrm{mg}$ extract) while EA-S extract contains syringic acid $(0.17 \pm 0.04 \mu \mathrm{g} / \mathrm{mg}$ extract) and emodin $(0.07 \pm 0.16 \mu \mathrm{g} / \mathrm{mg}$ extract). Moreover, MeOH-S extract contains catechin $(1.02 \pm 0.52 \mu \mathrm{g} / \mathrm{mg}$ extract $)$ while DW-F extract contains gentisic acid $(0.49 \pm 0.82 \mu \mathrm{g} / \mathrm{mg}$ extract). The detection of these polyphenols derives a direct correlation of plants potential with notified biological activities. All reported polyphenols possess a wide range of therapeutic activities. Caffeic acid has antioxidant [50], anticancer, anti-fibrosis, antihypertension [51,52], anti-hepatitis B virus [53] anti-inflammatory, anticoagulant activities [54]. Ferulic acid has anti-oxidant [55], cytotoxic [56], antiallergic, antiviral, anti-inflammatory, antimicrobial, anticoagulant, and hepatoprotective properties [57,58]. Reported activities of coumaric acid include antioxidant [59], anti-microbial [60], anti-leishmaniasis, cytotoxic [61]. Vanillic acid has hepato-protective [62] and anti-oxidant activities [63] while syringic acid has hepato-protective, neuro-protective, cardio-protective, anti-inflammatory, and hypoglycemic potential [64]. Gentisic acid possesses fibro growth factor inhibition [65], antimicrobial, antioxidant, anti-inflammatory, hepatoprotective, and neuroprotective activities [66]. Reported activities of catechin are anti-cancer [67], antimicrobial [68], hypolipidemic [69], vasodilator, antispasmodic, and bronchodilator activities [70]. Finally, emodin has anti-inflammatory, anti-cancer, antimicrobial, hepatoprotective potential [71,72]. Hence, detection of a wide range of polyphenols further manifests the therapeutic potential of $P$. roxburghii. Best to our knowledge, HPLC-DAD analysis of $P$. 
roxburghii was reported for the first time in the present study. Previously, HPLC analysis of polyphenols was carried out for Rosa roxburghii Tratt. leaf extracts. Approximately, 30 polyphenols were detected, which mainly includes gallic acid, myricetin, (+)-catechin, quercetin-3-O-galactoside, arbutin, and 3-hydroxybenzoic acid [73]. HPLC analysis of Pinus roxburghii barks and needles was carried out and quercetin was identified as the most abundant flavonol [11].
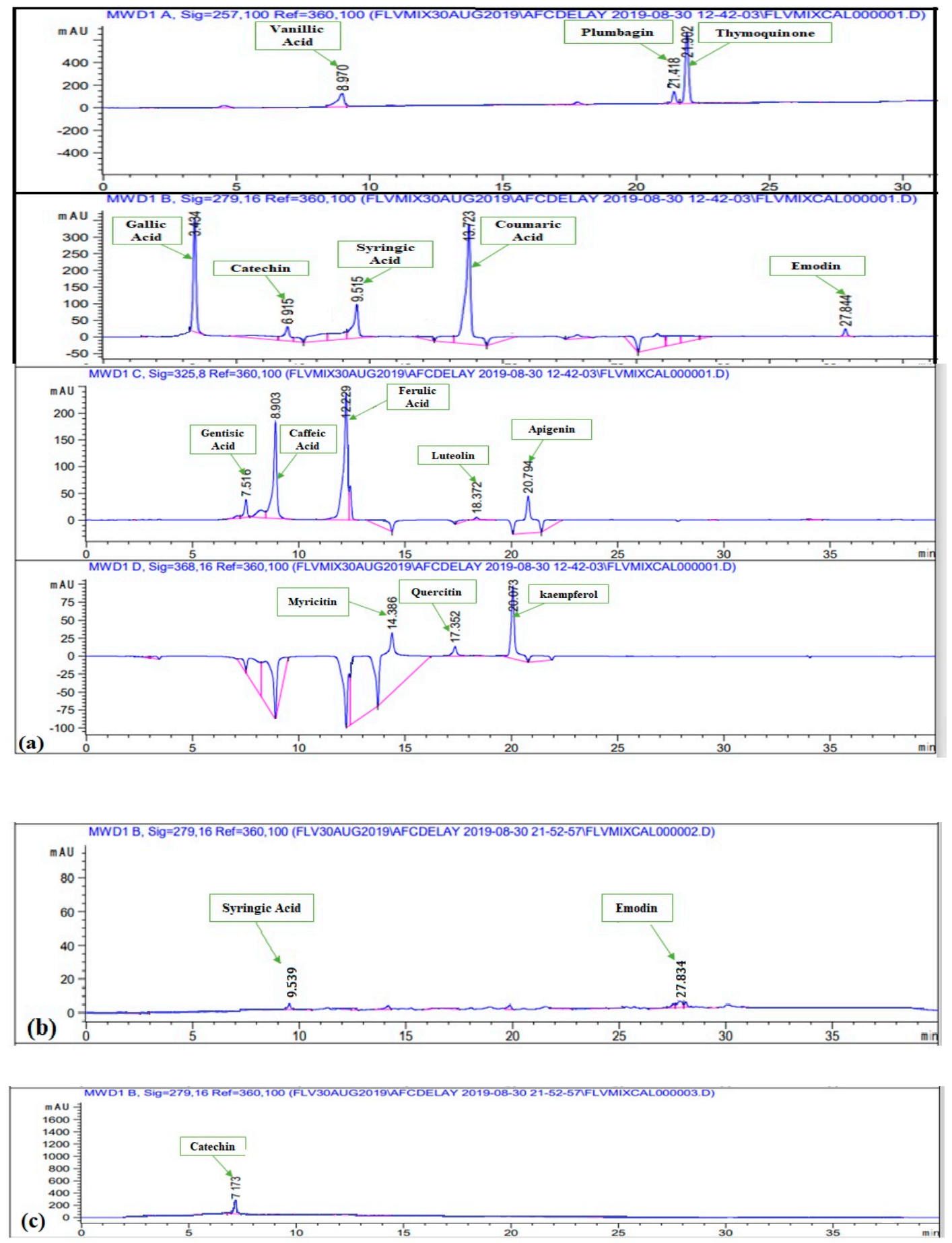

Figure 2. Cont. 

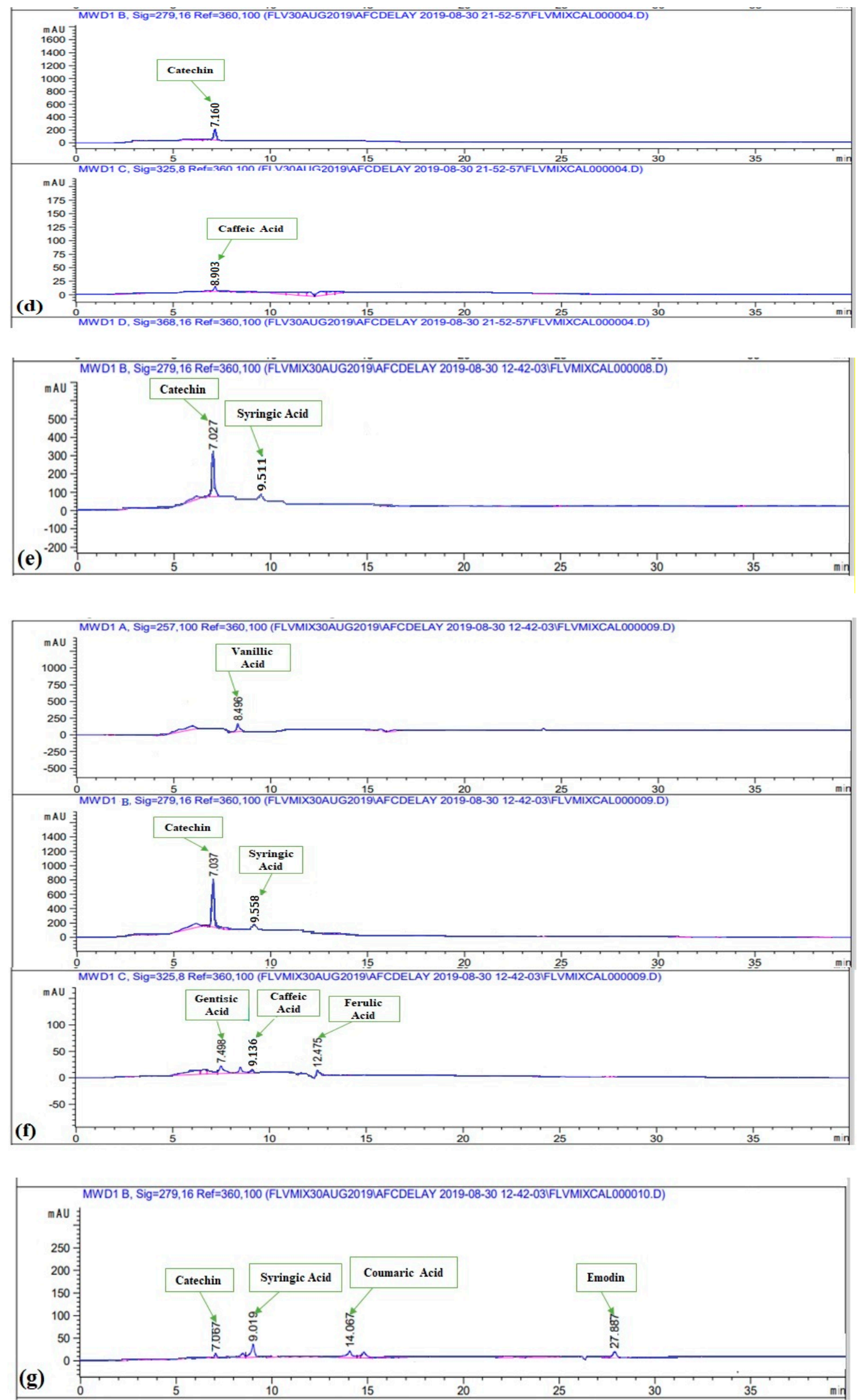

Figure 2. Cont. 

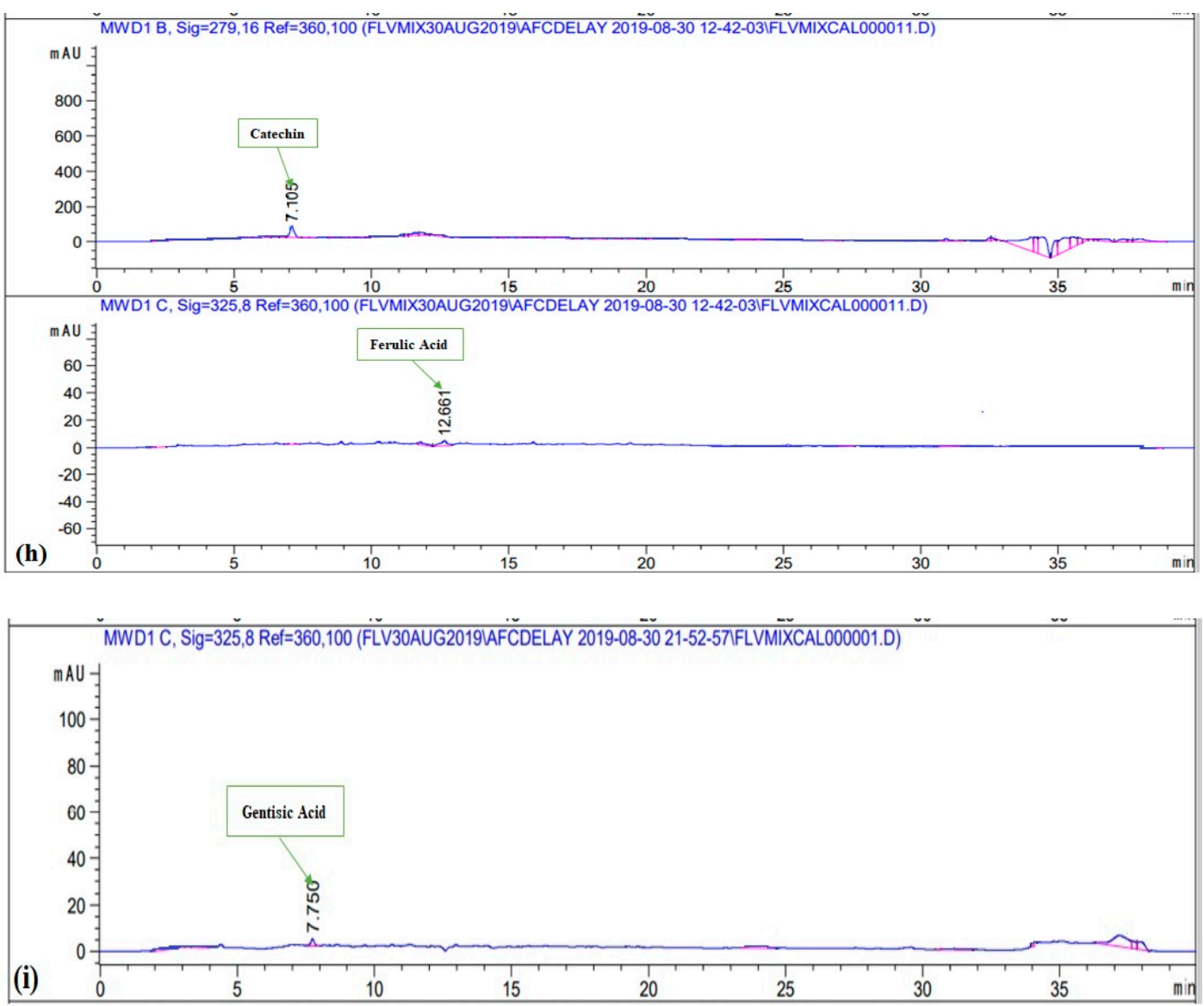

Figure 2. HPLC chromatograms of (a) standard polyphenols (b) EA-S (c) MeOH-S (d) DW-S (e) MeOH-L (f) DW-L (g) EA-F (h) MeOH-F (i) DW-F.

Table 1. Chemical profiling ( $\mu \mathrm{g} / \mathrm{mg}$ extract) of stem, leaf and fruit parts of P. roxburghii using HPLC-DAD.

\begin{tabular}{|c|c|c|c|c|c|c|c|c|c|c|}
\hline Class & Polyphenols & EA-S & MeOH-S & DW-S & EA-L & MeOH-L & DW-L & EA-F & MeOH-F & DW-F \\
\hline \multirow{3}{*}{$\begin{array}{l}\text { Cinnamic acid } \\
\text { derivatives }\end{array}$} & Caffeic Acid & - & - & $0.26 \pm 0.03 \mathrm{~m}$ & - & - & $0.35 \pm 0.06^{1}$ & - & - & - \\
\hline & Ferulic acid & - & - & - & - & - & $1.02 \pm 0.51^{\mathrm{c}}$ & - & $0.44 \pm 0.26^{\mathrm{k}}$ & - \\
\hline & Coumaric Acid & - & - & - & - & - & & $0.02 \pm 0.36 \mathrm{P}$ & - & - \\
\hline \multirow{4}{*}{$\begin{array}{l}\text { Benzoic acid } \\
\text { derivative }\end{array}$} & Vanillic Acid & - & - & - & - & - & $0.26 \pm 0.32 \mathrm{~m}$ & - & - & - \\
\hline & Gallic Acid & - & - & - & - & - & - & - & - & - \\
\hline & Syringic Acid & $0.17 \pm 0.04^{n}$ & - & - & - & $0.44 \pm 0.21 \mathrm{j}$ & $0.92 \pm 0.52 \mathrm{~d}$ & $0.76 \pm 0.42 \mathrm{f}$ & - & - \\
\hline & Gentisic Acid & - & - & - & - & - & $1.19 \pm 0.09 \mathrm{~b}$ & - & - & $0.49 \pm 0.82 \mathrm{j}$ \\
\hline \multirow{3}{*}{$\begin{array}{l}\text { Flavonol } \\
\text { flavonoids }\end{array}$} & Kaempferol & - & - & - & - & - & - & - & - & - \\
\hline & Quercetin & - & - & - & - & - & - & - & - & - \\
\hline & Myricitin & - & - & - & - & - & - & - & - & - \\
\hline $\begin{array}{l}\text { Flavan-3-ol } \\
\text { flavonoids }\end{array}$ & Catechin & - & $1.02 \pm 0.52 \mathrm{c}$ & $0.69 \pm 0.18 \mathrm{~g}$ & - & $0.74 \pm 0.01 \mathrm{fg}$ & $2.05 \pm 0.18^{\mathrm{a}}$ & $0.56 \pm 0.56^{\mathrm{i}}$ & $0.61 \pm 0.67 \mathrm{~h}$ & - \\
\hline \multirow{2}{*}{$\begin{array}{l}\text { Flavone } \\
\text { flavonoid }\end{array}$} & Luteolin & - & - & - & - & - & - & - & - & - \\
\hline & Apigenin & - & - & - & - & - & - & - & - & - \\
\hline Naphthoquinone & Plumbagin & - & - & - & - & - & - & - & - & - \\
\hline Anthraquinone & Emodin & $0.07 \pm 0.16^{\circ}$ & - & - & - & - & - & $0.87 \pm 23 \mathrm{e}$ & - & - \\
\hline Benzoquinone & Thymoquinone & - & - & - & - & - & - & - & - & - \\
\hline
\end{tabular}

$-=$ not detected. HPLC analysis was carried out in a triplicate manner and the data have been demonstrated as mean \pm standard deviation. The values with different superscripts $\left({ }^{a-p}\right)$ demonstrate significantly $(p<0.05)$ different mean values. 


\subsection{Biological Evaluation \\ 3.3.1. Antioxidant Assays DPPH Assay}

Metabolic processes within the body and environmental factors produce free radicals. Free radicals mainly include reactive oxygen species (ROS) which cause various ailments including ageing, carcinogenesis, mutagenesis, and cardiovascular abnormalities. Antioxidants are the agents, which counteract the effects of free radicals and limit oxidative stress [74]. DPPH assay is a standard method to investigate the free radical scavenging ability of test samples [75]. The percent free radical scavenging activity (\%FRSA) of test extracts was analyzed and results are given in Figure 3. Maximum \%FRSA was shown by MeOH-S and DW-L extracts ( $86 \pm 0.56 \%$ ) with $\mathrm{IC}_{50}$ values of $68 \pm 0.43,149 \pm 0.21 \mu \mathrm{g} / \mathrm{mL}$, respectively. Whereas, $\mathrm{nH}$ extracts of stem, leaf, and fruit were unable to express any free radical scavenging activity. Moreover, ascorbic acid showed 78\% FRSA with $\mathrm{IC}_{50}$ of $14.56 \mu \mathrm{g} / \mathrm{mL}$. We calculated the correlation of \%FRSA with TPC $\left(\mathrm{R}^{2}=0.8084\right)$ and TFC $\left(R^{2}=0.0211\right)$ which demonstrates that phenolic compounds other than flavonoids are mainly attributable to free radical scavenging activity. Previously reported \%FRSA of methanolic stem extracts of $P$. roxburghii was somewhat lower than calculated during our commenced research. Moreover, the current study revealed that DW-L extract of $P$. roxburghii also possesses a promising free radical scavenging potential. Highest extraction efficiency of DW-L extract provides another perspective to employ this extract as an antioxidant. Overall, our results were in accordance with a previous study which revealed that polar extracts possess better scavenging potential than non-polar extracts [25].

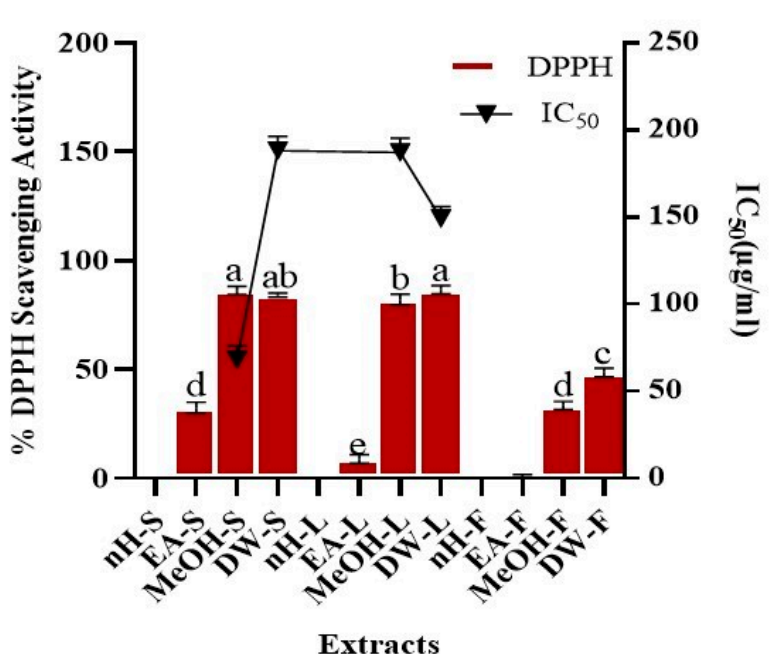

(a)

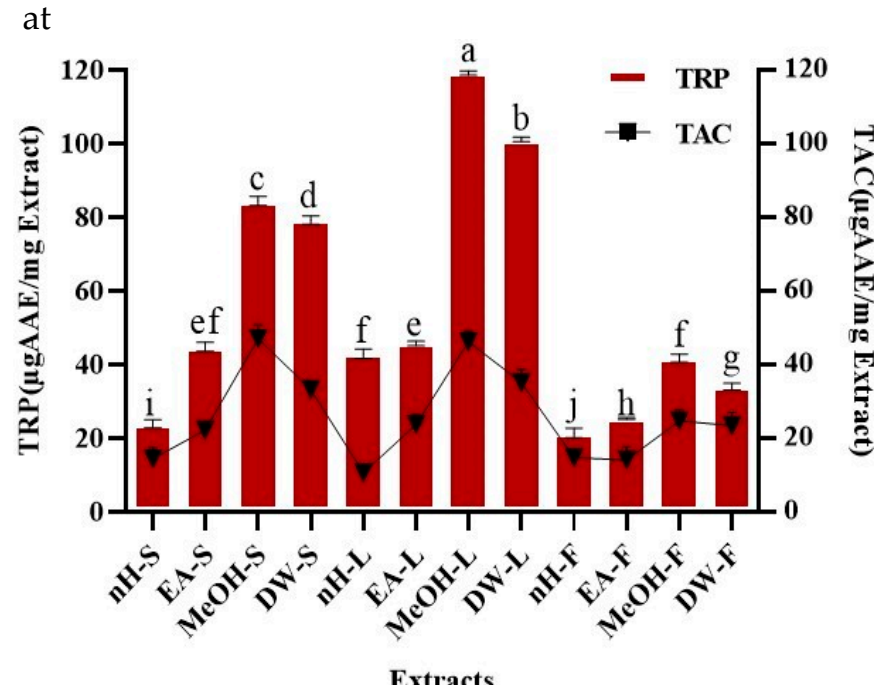

(b)

Figure 3. Demonstration of (a) \%DPPH radical scavenging activity (at $40 \mu \mathrm{g} / \mathrm{mL}$ concentration of test extracts) (b) TAC and TRP ( $\mu$ g AAE/mg) of P. roxburghii crude extracts. Assays were conducted in a triplicate manner and the data have been demonstrated as mean \pm standard deviation. Significantly different means $(p<0.05)$ are represented by different superscripts $\left({ }^{\mathrm{a}-\mathrm{j}}\right)$.

\section{Total Antioxidant Capacity (TAC)}

TAC of test extracts was calculated as shown in Figure 3. Maximum TAC was shown by $\mathrm{MeOH}-\mathrm{S}$ and $\mathrm{MeOH}-\mathrm{L}$ extracts, i.e., $48.65 \pm 0.52,46.07 \pm 0.07 \mu \mathrm{g} \mathrm{AAE} / \mathrm{mg}$ extract, respectively. Minimum TAC (10.91 $\pm 0.05 \mu \mathrm{g}$ AAE/mg extract) was expressed by $\mathrm{nH}-\mathrm{L}$ extract. We noticed a remarkable relationship between TAC and TPC $\left(R^{2}=0.744\right)$ which demonstrates that phytoconstituents producing antioxidant activity mainly belong to polyphenols. Moreover, the correlation between TAC and TFC $\left(R^{2}=0.1419\right)$ shows that flavonoids are not the main contributor to the antioxidant activity of test extracts. During a previous study, the estimated TAC of $P$. roxburghii stem part was significantly lower than 
that of the current study. This might be due to the fact that varying agro-climatic conditions can impact the type and quantity of phytoconstituents [41]. Moreover, the antioxidant capacity of different parts of $P$. roxburghii except stems, has been investigated for the first time [9]. Plant-derived antioxidants are considered better than synthetic antioxidants as they possess better compatibility with the human body [41], hence provide a justification for the exploitation of herbal products for therapeutic appraisal.

\section{Total Reducing Power (TRP)}

TRP was investigated for crude extracts and results are depicted in Figure 3. Maximum TRP was expressed by MeOH-L and DW-L extracts, i.e., $118.59 \pm 0.08,101.28 \pm 0,09 \mu \mathrm{g}$ $\mathrm{AAE} / \mathrm{mg}$ extract while $\mathrm{nH}-\mathrm{F}$ extract showed the least TRP, i.e., $20.48 \pm 0.52 \mu \mathrm{g}$ AAE/mg extract, respectively. A positive relation was notified between TPC and TRP $\left(\mathrm{R}^{2}=0.7251\right)$ in contrast to the correlation between TFC and TRP $\left(\mathrm{R}^{2}=0.1495\right)$ which demonstrates that phenolic constituents other than flavonoids are mainly accountable for reducing potential of plants. Reducing power of $P$. roxburghii stem part was previously investigated; however, the current study revealed that leaf part of this plant possesses better antioxidant potential [12]. Reducing power is mainly attributable to the presence of reductones which cleaves the free radical chain by hydrogen atom donation and participates in antioxidant action. Multiple studies have notified a close relationship between antioxidant activity and reducing power of crude extracts which is in support of our current research results [24,76].

\subsubsection{Antimicrobial Assays}

Antibacterial Assay

Antibacterial property of test extracts (100 $\mu \mathrm{g}$ per disc) was investigated against gram-negative (K. pneumoniae, P. aeruginosa, E. coli) and gram-positive (B. subtilis, S. aureus) bacteria as shown in Table 2 . Test extracts exhibiting zone of inhibition $\geq 12 \mathrm{~mm}$ were further subjected for MIC evaluation by employing the broth microdilution method. EA-L extract was highly active against B. subtilis (MIC $3.7 \mu \mathrm{g} / \mathrm{mL}$ ), K. pneumoniae (MIC $33.3 \mu \mathrm{g} / \mathrm{mL}$ ), and E. coli (MIC $3.7 \mu \mathrm{g} / \mathrm{mL}$ ) with $24 \pm 0.5,20 \pm 0.50,23 \pm 0.76 \mathrm{~mm}$ ZOIs, respectively. The ZOIs generated by the test extracts were equivalent to those produced by standards, i.e., roxithromycin and cefixime. Moreover, DMSO taken as negative control was unable to show inhibition. Overall, polar extracts showed better antibacterial potential than non-polar extracts. In a previous study, antibacterial potential of $P$. roxburghii $\mathrm{MeOH}$ leaf part was investigated, and results were in somewhat resemblance to our study. However, EA leaf extract was investigated for the first time, and it was noted that this extract possessed stronger antibacterial activity than previously reported $\mathrm{MeOH}$ leaf extract. Phenolics impart toxic effects to microbes either through interaction with sulfhydryl groups or proteins resulting in enzyme inhibition. Moreover, polyphenols generate heavy complexes with proteins which interact with bacterial adherence and disrupt the receptors on cell surface [26,77]. During the current study, a proficient amount of TPC and TFC was notified which might contribute to the antibacterial activity.

\section{Antifungal Assay}

During present study, MeOH-F extract $(100 \mu \mathrm{g} /$ disc) showed slight activity against $A$. flavus and A. fumigatus with $7 \pm 0.89$ and $8 \pm 0.98 \mathrm{~mm}$ ZOIs, respectively and MIC value of $>100 \mu \mathrm{g} / \mathrm{mL}$. MeOH-S extract was moderately active against $A$. flavus with $12 \pm 0.98 \mathrm{ZOI}$ and $>100 \mu \mathrm{g} / \mathrm{mL}$ MIC while other extracts were unable to show antifungal activity. Clotrimazole $(10 \mu \mathrm{g} / \mathrm{disc})$ showed $20 \pm 0.57$ to $31 \pm 1.1 \mathrm{~mm}$ ZOIs. A previous study reported the promising antifungal activity of seed and pericarp of $P$. roxburghii. However, during the present study; stem, leaf, and fruit parts of $P$. roxburghii showed slight to moderate antifungal active. Moreover, fungal strains used in current study were different from those used in previous study. Flavonoids and tannins can form complexes with extracellular proteins present in the cell wall of fungi and rupture the fungal membrane [78,79]. P. roxburghii 
contains tannins (ellagic acid, gallic acid, gallocatechin, ellagi- and gallo-tannins) and flavonoids (bioflavones) which might be a contributor to antifungal activity [49].

Table 2. Antibacterial activity and MIC values of $P$. roxburghii test extracts.

\begin{tabular}{|c|c|c|c|c|c|c|c|c|c|c|}
\hline \multirow{2}{*}{$\begin{array}{l}\text { Extract } \\
\text { Codes }\end{array}$} & \multicolumn{10}{|c|}{ Zone of Inhibition (mm) at $100 \mu \mathrm{g} / \mathrm{disc}$ and MIC $(\mu \mathrm{g} / \mathrm{mL})$} \\
\hline & S. A & MIC & B. $S$ & MIC & P. A & MIC & K. P & MIC & E. C & MIC \\
\hline nH-S & $7 \pm 0.29$ de & - & $11 \pm 0.2$ de & - & $7 \pm 0.15^{\mathrm{bc}}$ & - & $6 \pm 0.87$ ef & - & $11 \pm 0.51^{\mathrm{e}}$ & - \\
\hline EA-S & $7 \pm 0.31$ de & - & $9 \pm 0.5^{\mathrm{e}}$ & - & $8 \pm 0.31^{b}$ & - & $7 \pm 0.35^{\mathrm{e}}$ & - & $6 \pm 0.50^{g}$ & - \\
\hline MeOH-S & $10 \pm 0.36^{c}$ & - & $12 \pm 0.7^{\mathrm{d}}$ & $100^{a}$ & $7 \pm 0.10^{b c}$ & - & $10 \pm 0.76^{\mathrm{d}}$ & - & $13 \pm 0.50^{d}$ & $100^{a}$ \\
\hline DW-S & $7 \pm 0.36^{\text {de }}$ & - & $3 \pm 0.5^{g}$ & - & $6 \pm 0.10^{c}$ & - & $12 \pm 0.17^{c}$ & $100^{a}$ & $20 \pm 0.50^{b}$ & $33.3^{b}$ \\
\hline $\mathrm{nH}-\mathrm{L}$ & $8 \pm 0.7^{\mathrm{d}}$ & - & $12 \pm 0.5^{\mathrm{d}}$ & $100^{a}$ & $6 \pm 0.31^{c}$ & - & $7 \pm 0.55^{\mathrm{e}}$ & - & $7 \pm 0.31^{\mathrm{fg}}$ & - \\
\hline EA-L & $6 \pm 0.3^{\mathrm{e}}$ & - & $24 \pm 0.5^{a}$ & $3.7^{c}$ & $7 \pm 0.15^{b c}$ & - & $20 \pm 0.50^{a}$ & $33.3^{b}$ & $23 \pm 0.76^{a}$ & $3.7^{c}$ \\
\hline $\mathrm{MeOH}-\mathrm{L}$ & $8 \pm 0.36^{d}$ & - & $20 \pm 0.45^{b}$ & $33.3^{b}$ & $6 \pm 0.21^{c}$ & - & $14 \pm 0.76^{\mathrm{bc}}$ & $100^{\mathrm{a}}$ & $12 \pm \underset{\mathrm{de}}{ \pm 0.31}$ & $100^{\mathrm{a}}$ \\
\hline DW-L & $9 \pm 0.31^{\mathrm{cd}}$ & - & $9 \pm 0.5^{\mathrm{e}}$ & - & $7 \pm 0.25^{b c}$ & - & $12 \pm 0.51^{c}$ & $100^{a}$ & $6 \pm 0.76^{g}$ & - \\
\hline $\mathrm{nH}-\mathrm{F}$ & $5 \pm 0.15^{\mathrm{f}}$ & - & $7 \pm 0.7^{f}$ & - & $7 \pm 0.15^{b c}$ & - & $7 \pm 0.50^{\mathrm{e}}$ & - & $10 \pm 0.15^{\text {ef }}$ & - \\
\hline EA-F & $13 \pm 0.12^{b}$ & $100^{a}$ & $8 \pm 0.5^{\text {ef }}$ & - & $6 \pm 0.15^{c}$ & - & $19 \pm 0.58^{a b}$ & $33.3^{b}$ & $8 \pm 0.58^{f}$ & - \\
\hline $\mathrm{MeOH}-\mathrm{F}$ & $7 \pm 0.31$ de & - & $12 \pm 0.2^{d}$ & $100^{a}$ & $5 \pm 0.25^{c d}$ & - & $7 \pm 0.31^{\mathrm{e}}$ & - & $18 \pm 0.5^{c}$ & - \\
\hline DW-F & $10 \pm 0.32^{c}$ & - & $7 \pm 0.3^{f}$ & - & $5 \pm 0.33^{\mathrm{cd}}$ & - & $18 \pm 0.29^{b}$ & $33.3^{b}$ & $7 \pm 0.50 \mathrm{fg}$ & - \\
\hline Rox & $23 \pm 0.54^{a}$ & $1.11^{b}$ & $17 \pm 0.3^{c}$ & $3.33^{c}$ & - & - & - & - & - & - \\
\hline Cefix & - & - & - & - & $22 \pm 0.89^{a}$ & 1.11 & $20 \pm 1.2^{a}$ & $1.11^{\mathrm{c}}$ & $20 \pm 1.5^{b}$ & $3.33^{c}$ \\
\hline DMSO & - & - & - & - & - & - & - & - & - & - \\
\hline & & & $\begin{array}{l}\text { activity. } \mathrm{S} \\
\text { noniae, } \mathrm{E} \text {. } \\
\text { nanner an } \\
\text { scripts ( }{ }^{\mathrm{a}-\mathrm{g}}\end{array}$ & $\begin{array}{l}\text { Staph } \\
\text { cheri } \\
\text { data } \\
\text { ict sig }\end{array}$ & $\begin{array}{l}\text { cus aureus, } \\
\text { li. Rox = } \\
\text { been dem } \\
\text { intly }(p<0\end{array}$ & $\begin{array}{l}\text { Baci } \\
\text { arom } \\
\text { ted a } \\
\text { iffere }\end{array}$ & $\begin{array}{l}\text { ubtilis, P. A } \\
\text { Cefix = Ce } \\
\text { ean } \pm \text { stand } \\
\text { ean values. }\end{array}$ & $\begin{array}{l}\text { udom } \\
\text { le. A } \\
\text { levia }\end{array}$ & $\begin{array}{l}\text { aeruginosa, } \\
\text { was conduc } \\
\text { The values }\end{array}$ & $\begin{array}{l}=\text { Klebs } \\
\text { in a tr } \\
\text { diffe }\end{array}$ \\
\hline
\end{tabular}

\subsubsection{Enzyme Inhibition Assays}

$\alpha$-Amylase Inhibition Assay

The suppression of carbohydrate cleaving enzymes, i.e., $\alpha$-amylase and $\alpha$-glucosidase is a promising approach to reduce the blood glucose concentration in case of diabetes [27]. Inhibition of both enzymes impedes carbohydrate digestion and enhance the time required for carbohydrate digestion, limits rate of glucose absorption and ultimately prevents postprandial rise in plasma glucose level [80]. During the present study, $\alpha$-amylase inhibition potential of crude extracts was investigated and results are depicted in Figure 4. Maximum $\alpha$-amylase inhibition activity was expressed by EA-F and EA-S extracts, i.e., $67.37 \pm 0.05 \%$, $61.37 \pm 0.06 \%$ with $\mathrm{IC}_{50}$ values, i.e., $14.28 \pm 0.9,33.26 \pm 0.5 \mu \mathrm{g} / \mathrm{mL}$, respectively. Acarbose was employed as standard which showed $80.45 \pm 0.76 \% \alpha$-amylase inhibition with $\mathrm{IC}_{50}$ value of $34.85 \pm 0.21 \mu \mathrm{g} / \mathrm{mL}$. Results were in accordance with previous studies which reported that less polar extracts exhibited improved enzyme inhibition activity than highly polar extracts. These studies also notified a direct relationship between the concentration of phenolics and flavonoids with $\alpha$-amylase inhibition activity [81,82]. However, the current study did not notice any significant relation of TPC $\left(R^{2}=0.343\right)$, and TFC $\left(R^{2}=0.0008\right)$ with $\alpha$-amylase inhibition potential.

\section{$\alpha$-Glucosidase Inhibition Assay}

Antidiabetic activity of $P$. roxburgii was further confirmed by estimation of $\alpha$-glucosidase inhibition potential of crude extracts and results are depicted in Figure 4. Maximum $\alpha-$ glucosidase inhibition $\left(80 \pm 0.78 \%\right.$ ) was shown by $\mathrm{nH}-\mathrm{L}$, nH-S, and DW-S extracts with $\mathrm{IC}_{50}$ values, i.e., $90.21 \pm 0.02,93 \pm 0.078,94.11 \pm 0.99 \mu \mathrm{g} / \mathrm{mL}$, respectively. Just like $\alpha$-amylase inhibition, there was no positive relationship of TPC $\left(R^{2}=0.1971\right)$ and TFC $\left(R^{2}=0.1231\right)$ with $\alpha$-glucosidase inhibition. Acarbose and miglitol are commercially available $\alpha$-glucosidase inhibitors which hinder the carbohydrate absorption and reduce post-prandial escalation in glucose levels [83]. However, these agents possess severe gastrointestinal adverse effects 
such as diarrhea and flatulence [84]. $\alpha$-amylase inhibitors have been reported to be present in plants which helps them to combat predators [85].

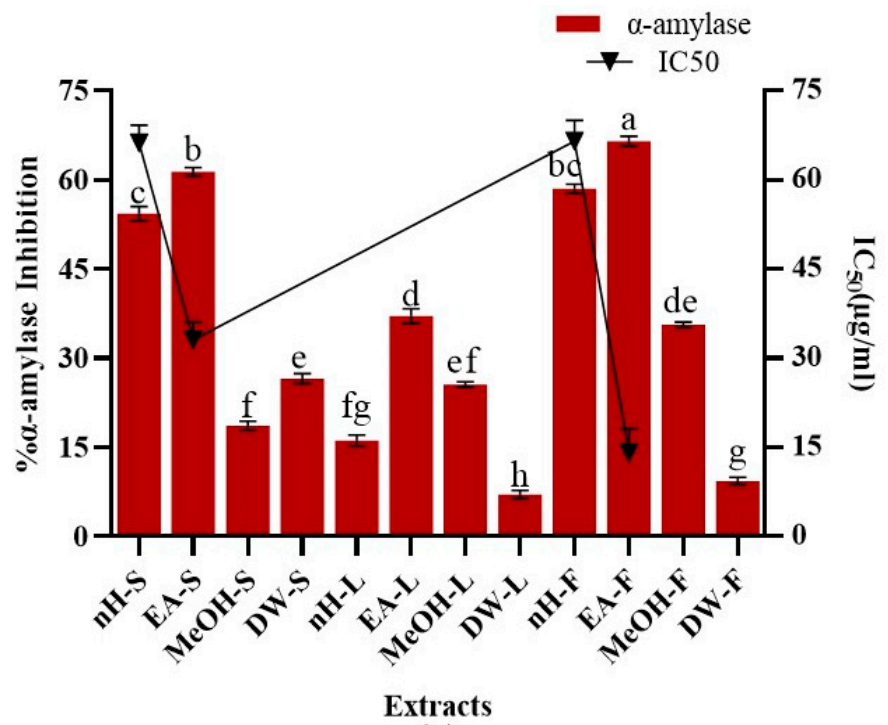

(a)

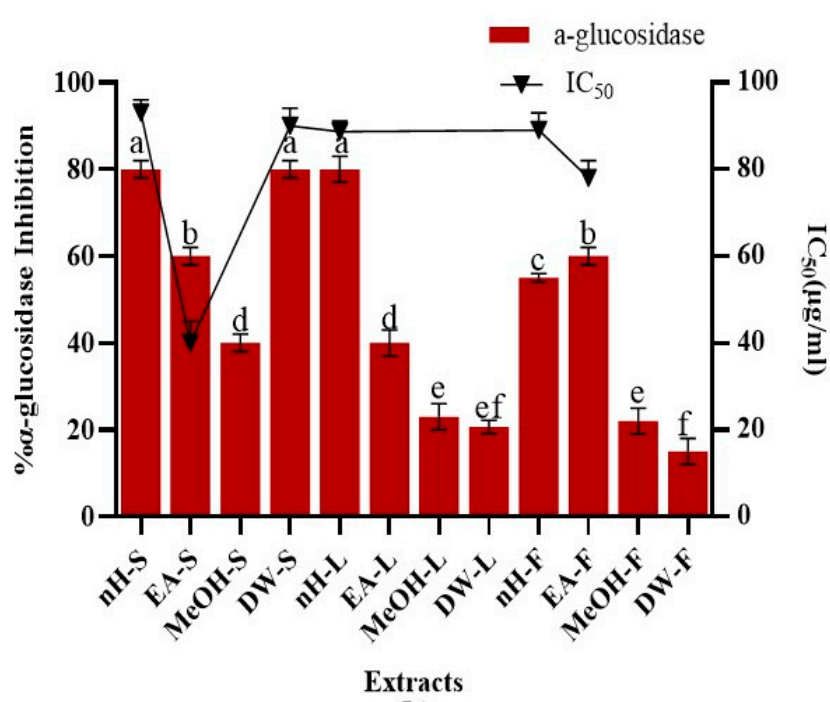

(b)

Figure 4. Demonstration of (a) $\alpha$-amylase inhibition and (b) $\alpha$-glucosidase inhibition potential of P. roxburghii crude extracts. Assays were conducted in a triplicate manner and the data have been demonstrated as mean \pm standard deviation. Significantly different means $(p<0.05)$ are represented by different superscripts $\left({ }^{\mathrm{a}-\mathrm{h}}\right)$.

A detailed study was executed for the first time to investigate $\alpha$-amylase and $\alpha$ glucosidase inhibition potential of different parts of $P$. roxburghii. Previous study demonstrated that plants containing tannins such as Camelia sinensis Var., Artocarpus heterophyllus Lam., Persea Americana Mil., and Syzygium polyanthum Walp. are potent inhibitors of $\alpha$-glucosidase [86]. A wide range of tannins such as ellagic acid, gallic acid, gallocatechin, ellagi- and gallo-tannins are present in $P$. roxburghii might be involved behind the $\alpha$-glucosidase inhibition activity [49]. However, further studies are needed to prove this hypothesis.

\subsubsection{Preliminary Toxicity Potential \\ Brine Shrimp Lethality Assay}

Brine shrimp lethality assay is a preliminary method to investigate the cytotoxic effect of test samples [87]. Brine shrimp lethality potential was noticed to be in direct relation to the concentration of test extracts (Table 3). Out of the twelve extracts subjected for estimation of cytotoxic activity, $41.67 \%$ of the extracts $\left(\mathrm{LC}_{50}<50 \mu \mathrm{g} / \mathrm{mL}\right)$ were considered as extremely cytotoxic while $33.33 \%$ of crude extracts $\left(\mathrm{LC}_{50} \geq 50\right.$ but $\left.\leq 200 \mu \mathrm{g} / \mathrm{mL}\right)$ were classified as moderately cytotoxic. Other $25 \%$ of the extracts $(>200 \mu \mathrm{g} / \mathrm{mL})$ were categorized as weakly cytotoxic. Overall, DW-F extract was noticed as most cytotoxic extract showing $\mathrm{LC}_{50} 9.36 \pm 0.91 \mu \mathrm{g} / \mathrm{mL}$ while $\mathrm{LC}_{50}$ of doxorubicin (positive control) was $5.93 \mu \mathrm{g} / \mathrm{mL}$. Previously, brine shrimp lethality potential of methanolic seed extract was investigated and mild cytotoxicity potential was reported [88]. Undertaken study was carried out on various other parts of $P$. roxburghii and promising brine shrimp lethality potential of $\mathrm{nH}$ and DW extracts of fruit was revealed for the first time. During the present study, $100 \%$ of the test extracts exhibited $\mathrm{LC}_{50}$ values of less than $1000 \mu \mathrm{g} / \mathrm{mL}$, referring to the existence of cytotoxic phytometabolites in the subject plant. 
Table 3. Brine shrimp lethality and protein kinase inhibition potential of crude extracts of P. roxburghii.

\begin{tabular}{|c|c|c|c|c|c|c|c|}
\hline \multirow[b]{2}{*}{ Extract Codes } & \multicolumn{5}{|c|}{ \% Brine Shrimp Mortality } & \multicolumn{2}{|c|}{ Protein Kinase Inhibition } \\
\hline & $\begin{array}{c}200 \\
(\mu \mathrm{g} / \mathrm{mL})\end{array}$ & $\begin{array}{c}100 \\
(\mu \mathrm{g} / \mathrm{mL})\end{array}$ & $\begin{array}{c}50 \\
(\mu \mathrm{g} / \mathrm{mL})\end{array}$ & $\begin{array}{c}25 \\
(\mu \mathrm{g} / \mathrm{mL})\end{array}$ & $\begin{array}{c}\mathrm{LC}_{50} \\
(\mu \mathrm{g} / \mathrm{mL})\end{array}$ & $\begin{array}{l}\text { Clear Zone } \\
\text { (mm) }\end{array}$ & $\begin{array}{c}\text { Bald Zone } \\
(\mathrm{mm})\end{array}$ \\
\hline $\mathrm{nH}-\mathrm{S}$ & $70 \pm 10^{b}$ & $40 \pm 7.5^{\mathrm{d}}$ & $2 \pm 11.5^{g}$ & $20 \pm 0^{\mathrm{e}}$ & $130.93 \pm 0.56^{b}$ & - & - \\
\hline EA-S & $100 \pm 0^{a}$ & $100 \pm 0^{a}$ & $50 \pm 5.7^{b}$ & $30 \pm 0^{d}$ & $39.52 \pm 0.42^{f}$ & - & - \\
\hline MeOH-S & $100 \pm 0^{a}$ & $40 \pm 5.7^{\mathrm{d}}$ & $40 \pm 0^{c}$ & $30 \pm 7.5^{\mathrm{d}}$ & $88.51 \pm 0.59^{\mathrm{e}}$ & - & - \\
\hline DW-S & $100 \pm 0^{a}$ & $50 \pm 0^{c}$ & $0 \pm 0^{h}$ & $0 \pm 0^{g}$ & $100 \pm 0.67^{c}$ & - & - \\
\hline nH-L & $30 \pm 0^{c}$ & $30 \pm 0^{\mathrm{e}}$ & $0 \pm 0^{\mathrm{h}}$ & $0 \pm 0^{g}$ & $>200 \pm 0.73^{a}$ & - & - \\
\hline EA-L & $100 \pm 5.7^{a}$ & $100 \pm 0^{a}$ & $70 \pm 0^{a}$ & $60 \pm 7.5^{b}$ & $20 \pm 1.16^{g}$ & - & - \\
\hline $\mathrm{MeOH}-\mathrm{L}$ & $30 \pm 11.5^{c}$ & $20 \pm 0^{f}$ & $10 \pm 0^{f}$ & $10 \pm 5.7$ & $>200 \pm 1.52^{a}$ & - & - \\
\hline DW-L & $100 \pm 0^{a}$ & $50 \pm 0^{c}$ & $30 \pm 5.7^{d}$ & $20 \pm 0^{\mathrm{e}}$ & $93.1 \pm 0.36^{\mathrm{d}}$ & - & - \\
\hline $\mathrm{nH}-\mathrm{F}$ & $100 \pm 0^{a}$ & $100 \pm 0^{a}$ & $70 \pm 0^{a}$ & $70 \pm 0^{a}$ & $18.84 \pm 0.49$ gh & - & $7 \pm 0.97^{a b}$ \\
\hline EA-F & $100 \pm 7.5^{a}$ & $90 \pm 7.5^{b}$ & $50 \pm 0^{b}$ & $40 \pm 0^{c}$ & $35.5 \pm 0.53^{g}$ & - & - \\
\hline $\mathrm{MeOH}-\mathrm{F}$ & $30 \pm 5.7^{c}$ & $16 \pm 0 \mathrm{~g}$ & $16 \pm 0^{\mathrm{e}}$ & $10 \pm 0^{\mathrm{f}}$ & $>200 \pm 1.21^{a}$ & - & - \\
\hline DW-F & $100 \pm 0^{a}$ & $100 \pm 0^{a}$ & $0 \pm 0^{h}$ & $60 \pm 0^{b}$ & $9.36 \pm 0.91^{\mathrm{i}}$ & - & $8 \pm 0.4^{a}$ \\
\hline
\end{tabular}

\section{Protein Kinase Inhibition Assay}

Protein kinase regulates multiple functions of the cell cycle including apoptosis, metabolism, growth, and differentiation. In the case of human cancers, irregularities of growth factor signaling pathways were notified. Hence, protein kinase inhibition can serve as a target for drug development by overcoming the irregularities in signaling pathways [89]. Protein kinase inhibition activity of the test extracts $(100 \mu \mathrm{g} / \mathrm{disc})$ was investigated as well (Table 3). DW and $\mathrm{nH}$ fruit extracts showed $8 \pm 0.4$ and $7 \pm 0.97 \mathrm{~mm}$ bald phenotype zones, respectively while no clear zone was found. The remaining extracts were unable to express any protein kinase inhibition activity. The absence of ZOI in case of DMSO confirmed the non-toxic effect of negative control. Protein kinase is involved in the regulation of various processes of cell cycle, i.e., control of cycle growth, metabolism, differentiation, and apoptosis. Abnormalities of growth factor signaling pathways have been notified in various forms of human cancer. Hence, protein kinase inhibitors capable to repair the dysregulations in these signaling pathways can act as promising targets for anticancer drug development [89]. Previously, this plant has shown significant anticancer potential against different cancer cell lines. A combined herbal therapy comprised of Punica granatum and P. roxburghii showed strong cytotoxic activity against HepG2 hepatocellular carcinoma cell line in correlation with its antioxidant effect, hence proving the significant anticancer potential of the subject plant in the current study [90]. Not only the organic solvents extracts but the green silver nanoparticles synthesized using $P$. roxburghii leaves extracts depicted stupendous inhibitory activity against PANC-1, HCT-116 and MDA-MB-231 cell lines showing its potential to reduce the proliferation of cancerous cells [91]. During the present study, P. roxburghii DW extract showed mild protein kinase inhibition activity. The activity is supported by the results of a previous finding in which water extracts of Sargassum oligocystum depicted significant cytotoxic and antiproliferative activity against K562 and Daudi cell lines [92]. The linkage of protein kinase inhibitory activity and anticancer effects persuaded to draw the relation between previous findings and the results of the current studies. Although, a detailed study has been conducted for the first time to investigate the protein kinase inhibition potential of multiple parts of $P$. roxburghii. 


\section{Conclusions}

Undertaken study demonstrates the polyphenolic analysis and pharmacological potential of crude extracts. Overall, leaf part showed maximum biological activities as compared to the stem and fruit parts of $P$. roxburghii. In case of leaf part $\mathrm{DW}$ and $\mathrm{MeOH}$ extracts were highly active whereas EA and $\mathrm{nH}$ extracts also showed some biological activities. The present study suggests that $P$. roxburghii crude extracts are a potential reservoir of phytoconstituents instigating the considerable antioxidant, antibacterial, antidiabetic, and cytotoxic compounds. These bioactive phytoconstituents could act as unique frameworks in a quest for innovative drugs. we recommend that subsequent studies should be carried out for the isolation of bioactive compounds from P. roxburghii (especially DW-L extract), which can be considered as potential candidates for the treatment of different ailments.

Author Contributions: A.N. executed all experimental work and prepared initial draft of the manuscript. M.Z.I.K. and M.A. compiled the data and were involved in the written work. N.A., M.K.O., A.A.-H. and W.H.A.-Q. were involved in H.A. analysis and interpretation of data. I.-u.-H. contributed in study design, supervised the execution of experiments and revised the manuscript. All authors have read and agreed to the published version of the manuscript.

Funding: This research was funded by King Saud University, Riyadh, Saudi Arabia under Researchers Support Project number (RSP-2021/374).

Institutional Review Board Statement: Not applicable.

Informed Consent Statement: Not applicable.

Data Availability Statement: Data sharing not applicable.

Acknowledgments: The authors would like to acknowledge Rizwana Aleem Qureshi, Department of Plant Sciences, Faculty of Biological Sciences, Quaid-i-Azam University Islamabad, Pakistan, for the identification of the plant, used in the current study. Authors also appreciate Researchers Support Project number (RSP-2021/374) King Saud University, Riyadh, Saudi Arabia for support.

Conflicts of Interest: Authors declare no conflict of interests.

Sample Availability: The crude extracts prepared for the current study are available from the authors.

\section{References}

1. Auddy, B.; Ferreira, M.; Blasina, F.; Lafon, L.; Arredondo, F.; Dajas, F.; Tripathi, P.; Seal, T.; Mukherjee, B. Screening of anti-oxidant activity of three Indian medicinal plants, traditionally used for the management of neurodegenerative diseases. J. Ethnopharmacol. 2003, 84, 131-138. [CrossRef]

2. Mustafa, G.; Arif, R.; Atta, A.; Sharif, S.; Jamil, A. Bioactive compounds from medicinal plants and their importance in drug discovery in Pakistan. Matrix Sci. Pharma 2017, 1, 17-26. [CrossRef]

3. Orhan, I.E. Pharmacognosy: Science of natural products in drug discovery. Bioimpacts 2014, 4, 109-110. [CrossRef] [PubMed]

4. Ahmed, H.; Irshad Khan, M.Z.; Waseem, D.; Nazli, A.; Waleed Baig, M. Phytochemical Analysis and antioxidant potential of Ficus benghalensis L. J. Bioresour. Manag. 2017, 4, 3-29.

5. Verma, S.; Singh, S. Current and future status of herbal medicines. Vet. World 2008, 1, 347-350. [CrossRef]

6. Sasidharan, S.; Chen, Y.; Saravanan, D.; Sundram, K.; Latha, L.Y. Extraction, isolation and characterization of bioactive compounds from plants' extracts. Afr. J. Tradit. Complement. Altern. Med. 2011, 8, 1-10. [CrossRef]

7. Yao, J.; Weng, Y.; Dickey, A.; Wang, K.Y. Plants as factories for human pharmaceuticals: Applications and challenges. Int. J. Mol. Sci. 2015, 16, 28549-28565. [CrossRef] [PubMed]

8. Cragg, G.M.; Newman, D.J. Natural products: A continuing source of novel drug leads. Biochem. Biophys. Acta Gen. Subj. 2013, 1830, 3670-3695. [CrossRef]

9. Simoens, C.; Vermorken, J.B.; Korst, A.E.; Pauwels, B.; De Pooter, C.M.; Pattyn, G.G.; Lambrechts, H.A.; Breillout, F.; Lardon, F. Cell cycle effects of vinflunine, the most recent promising Vinca alkaloid, and its interaction with radiation, in vitro. Cancer Chemother. Pharmacol. 2006, 58, 210-218. [CrossRef]

10. Mok, T.S.; Wu, Y.-L.; Thongprasert, S.; Yang, C.-H.; Chu, D.-T.; Saijo, N.; Sunpaweravong, P.; Han, B.; Margono, B.; Ichinose, Y. Gefitinib or carboplatin-paclitaxel in pulmonary adenocarcinoma. N. Engl. J. Med. 2009, 361, 947-957. [CrossRef]

11. Naeem, I.; Taskeen, A.; Mubeen, H.; Maimoona, A. Characterization of flavonols present in barks and needles of Pinus wallichiana and Pinus roxburghii. Chem. Asian J. 2010, 22, 41-47.

12. Shahwar, D.; Raza, M.A.; Saeed, A.; Riasat, M.; Chattha, F.I.; Javaid, M.; Ullah, S. Antioxidant potential of the extracts of Putranjiva roxburghii, Conyza bonariensis, Woodfordia fruiticosa and Senecio chrysanthemoids. Afr. J. Biotechnol. 2012, 11, 4288-4295. 
13. Chaudhary, N.S.; Shee, C.; Islam, A.; Ahmad, F.; Yernool, D.; Kumar, P.; Sharma, A.K. Purification and characterization of a trypsin inhibitor from Putranjiva roxburghii seeds. Phytochemistry 2008, 69, 2120-2126. [CrossRef]

14. Tripathi, N.; Kumar, N. Putranjiva roxburghii oil-A potential herbal preservative for peanuts during storage. J. Stored Prod. Res. 2007, 43, 435-442. [CrossRef]

15. Vidhya, U.; Nishteswar, K. Putranjiva-a herb for pumsavana (male progeny facilitator)? Int. J. Ayurveda Pharma Res. 2015, 3, 11-16.

16. Mishra, S.; Kumar, S.; Darokar, M.P.; Shanker, K. Novel bioactive compound from the bark of Putranjiva roxburghii Wall. Nat. Prod. Res. 2019, 35, 1-3. [CrossRef]

17. Garg, H.; Mitra, C. Putranjiva roxburghii wall.-II: Triterpenes of the trunk bark. Phytochemistry 1968, 7, 2053-2055. [CrossRef]

18. Abhimanyu, K.K.; Ravindra, C.S.; Avanapu, R.S. A validated HPTLC method for the quantification of friedelin in Putranjiva roxburghii Wall extracts and in polyherbal formulations. Bull. Fac. Pharm. Cairo Univ. 2017, 55, 79-84. [CrossRef]

19. Garg, H.; Mitra, C. Roxburghonic acid-A friedelane triterpenoid keto acid of the leaf of Putranjiva roxburghii. Phytochemistry 1971, 10, 865-869. [CrossRef]

20. Sen, S.; Chakraborty, R.; De, B. Challenges and opportunities in the advancement of herbal medicine: India's position and role in a global context. J. Herb. Med. 2011, 1, 67-75. [CrossRef]

21. Fatima, H.; Khan, K.; Zia, M.; Ur-Rehman, T.; Mirza, B.; Haq, I.-U. Extraction optimization of medicinally important metabolites from Datura innoxia Mill.: An in vitro biological and phytochemical investigation. BMC Complement. Altern. Med. 2015, 15, 1-18. [CrossRef] [PubMed]

22. Khan, M.Z.I.; Zahra, S.S.; Ahmed, M.; Fatima, H.; Mirza, B.; Haq, I.-u.; Khan, S.U. Polyphenolic profiling of Ipomoea carnea Jacq. by HPLC-DAD and its implications in oxidative stress and cancer. Nat. Prod. Res. 2019, 33, 2099-2104. [CrossRef]

23. Bibi, G.; Ullah, N.; Mannan, A.; Mirza, B. Antitumor, cytotoxic and antioxidant potential of Aster thomsonii extracts. Afr. J. Pharmacy Pharmacol. 2011, 5, 252-258.

24. Ahmed, M.; Fatima, H.; Qasim, M.; Gul, B. Polarity directed optimization of phytochemical and in vitro biological potential of an indigenous folklore: Quercus dilatata Lindl. ex Royle. BMC Complement. Altern. Med. 2017, 17, 1-16. [CrossRef] [PubMed]

25. Zahra, S.S.; Ahmed, M.; Qasim, M.; Gul, B.; Zia, M.; Mirza, B.; Haq, I.-u. Polarity based characterization of biologically active extracts of Ajuga bracteosa Wall. ex Benth. and RP-HPLC analysis. BMC Complement. Altern. Med. 2017, 17, 443-456. [CrossRef] [PubMed]

26. Nasir, B.; Ahmad, M.; Zahra, S.S.; Fatima, H.; Ur-Rehman, T. Pharmacological evaluation of Fumaria indica (hausskn.) Pugsley; a traditionally important medicinal plant. Pak. J. Bot. 2017, 49, 119-132.

27. Nair, S.S.; Kavrekar, V.; Mishra, A. In vitro studies on alpha amylase and alpha glucosidase inhibitory activities of selected plant extracts. Eur. J. Exp. Biol. 2013, 3, 128-132.

28. Azwanida, N. A review on the extraction methods use in medicinal plants, principle, strength and limitation. Med. Aromat. Plants 2015, 4, 2167-0412.

29. Trusheva, B.; Trunkova, D.; Bankova, V. Different extraction methods of biologically active components from propolis: A preliminary study. Chem. Cent. J. 2007, 1, 1-4. [CrossRef]

30. Jha, A.K.; Prasad, K.; Prasad, K.; Kulkarni, A. Plant system: Nature's nanofactory. Colloids Surf. B 2009, 73, 219-223. [CrossRef]

31. Saraf, S. Applications of novel drug delivery system for herbal formulations. Fitoterapia 2010, 81, 680-689.

32. Keshav, P.; Goyal, D.K.; Kaur, S. GC-MS screening and antiparasitic action of Putranjiva roxburghii leaves against sensitive and resistant strains of Leishmania donovani. J. Parasit. Dis. 2021, 45, 1-12. [CrossRef] [PubMed]

33. Kumar, S.; Yadav, M.; Yadav, A.; Yadav, J. Impact of spatial and climatic conditions on phytochemical diversity and in vitro antioxidant activity of Indian Aloe vera (L.) Burm. f. Afr. J. Bot. 2017, 111, 50-59. [CrossRef]

34. Dai, J.; Mumper, R.J. Plant phenolics: Extraction, analysis and their antioxidant and anticancer properties. Molecules 2010, 15, 7313-7352. [CrossRef] [PubMed]

35. Li, A.-N.; Li, S.; Zhang, Y.-J.; Xu, X.-R.; Chen, Y.-M.; Li, H.-B. Resources and biological activities of natural polyphenols. Nutrients 2014, 6, 6020-6047. [CrossRef]

36. Parr, A.J.; Bolwell, G.P. Phenols in the plant and in man. The potential for possible nutritional enhancement of the diet by modifying the phenols content or profile. J. Sci. Food Agric. 2000, 80, 985-1012.

37. Croft, K.D. The Chemistry and biological effects of flavonoids and phenolic acids. Ann. N. Y. Acad. Sci. 1998, 854, 435-442. [CrossRef] [PubMed]

38. Cos, P.; Ying, L.; Calomme, M.; Hu, J.P.; Cimanga, K.; Van Poel, B.; Pieters, L.; Vlietinck, A.J.; Berghe, D.V. Structure-activity relationship and classification of flavonoids as inhibitors of xanthine oxidase and superoxide scavengers. J. Nat. Prod. 1998, 61, 71-76. [CrossRef]

39. Al-Snafi, A.E. Phenolics and flavonoids contents of medicinal plants, as natural ingredients for many therapeutic purposes-a review. IOSR J. Pharm. 2020, 10, 42-81.

40. Kubo, I.; Fujita, K.-I.; Nihei, K.-I.; Nihei, A. Antibacterial activity of akyl gallates against Bacillus subtilis. J. Agric. Food Chem. 2004, 52, 1072-1076. [CrossRef]

41. Chen, F.; Long, X.; Yu, M.; Liu, Z.; Liu, L.; Shao, H. Phenolics and antifungal activities analysis in industrial crop Jerusalem artichoke (Helianthus tuberosus L.) leaves. Ind. Crops Prod. 2013, 47, 339-345. [CrossRef]

42. Uozaki, M.; Yamasaki, H.; Katsuyama, Y.; Higuchi, M.; Higuti, T.; Koyama, A.H. Antiviral effect of octyl gallate against DNA and RNA viruses. Antivir. Res. 2007, 73, 85-91. [CrossRef] 
43. You, B.R.; Moon, H.J.; Han, Y.H.; Park, W.H. Gallic acid inhibits the growth of HeLa cervical cancer cells via apoptosis and/or necrosis. Food Chem. Toxicol. 2010, 48, 1334-1340. [CrossRef]

44. Kumar, S.; Pandey, A.K. Chemistry and biological activities of flavonoids: An overview. Sci. World J. 2013, 2013, 1-16. [CrossRef] [PubMed]

45. Pereira, D.M.; Valentão, P.; Pereira, J.A.; Andrade, P.B. Phenolics: From chemistry to biology. Molecules 2009, 14, 2202-2211. [CrossRef]

46. Jucá, M.M.; Cysne Filho, F.M.S.; de Almeida, J.C.; Mesquita, D.d.S.; Barriga, J.R.d.M.; Dias, K.C.F.; Barbosa, T.M.; Vasconcelos, L.C.; Leal, L.K.A.M.; Ribeiro, J.E. Flavonoids: Biological activities and therapeutic potential. Nat. Prod. Res. 2020, $34,692-705$. [CrossRef] [PubMed]

47. Xu, S.-J.; Wang, X.; Wang, T.-Y.; Lin, Z.-Z.; Hu, Y.-J.; Huang, Z.-L.; Yang, X.-J.; Xu, P. Flavonoids from Rosa roxburghii Tratt prevent reactive oxygen species-mediated DNA damage in thymus cells both combined with and without PARP-1 expression after exposure to radiation in vivo. Aging 2020, 12, 16368-16389. [CrossRef]

48. Ye, S.; Shao, Q.; Zhang, A. Anoectochilus roxburghii: A review of its phytochemistry, pharmacology, and clinical applications. J. Ethnopharmacol. 2017, 209, 184-202. [CrossRef]

49. Gupta, M. A review of pharmacological properties, pharmacognosy and therapeutic actions of Putranjiva roxburghii Wall (Putranjiva). Int. J. Herb. Med. 2016, 4, 104-108.

50. Chen, J.H.; Ho, C.-T. Antioxidant activities of caffeic acid and its related hydroxycinnamic acid compounds. J. Agric. Food Chem. 1997, 45, 2374-2378. [CrossRef]

51. Jiang, R.-W.; Lau, K.-M.; Hon, P.-M.; Mak, T.C.; Woo, K.-S.; Fung, K.-P. Chemistry and biological activities of caffeic acid derivatives from Salvia miltiorrhiza. Curr. Med. Chem. 2005, 12, 237-246. [CrossRef]

52. Espíndola, K.M.M.; Ferreira, R.G.; Narvaez, L.E.M.; Silva Rosario, A.C.R.; da Silva, A.H.M.; Silva, A.G.B.; Vieira, A.P.O.; Monteiro, M.C. Chemical and pharmacological aspects of caffeic acid and its activity in hepatocarcinoma. Front. Oncol. 2019, 9, 541-551. [CrossRef]

53. Wang, G.-F.; Shi, L.-P.; Ren, Y.-D.; Liu, Q.-F.; Liu, H.-F.; Zhang, R.-J.; Li, Z.; Zhu, F.-H.; He, P.-L.; Tang, W. Anti-hepatitis B virus activity of chlorogenic acid, quinic acid and caffeic acid in vivo and in vitro. Antivir. Res. 2009, 83, 186-190. [CrossRef] [PubMed]

54. Chao, P.-C.; Hsu, C.-C.; Yin, M.-C. Anti-inflammatory and anti-coagulatory activities of caffeic acid and ellagic acid in cardiac tissue of diabetic mice. Nutr. Metab. 2009, 6, 1-8. [CrossRef] [PubMed]

55. Kikuzaki, H.; Hisamoto, M.; Hirose, K.; Akiyama, K.; Taniguchi, H. Antioxidant properties of ferulic acid and its related compounds. J. Agric. Food Chem. 2002, 50, 2161-2168. [CrossRef]

56. Ogiwara, T.; Satoh, K.; Kadoma, Y.; Murakami, Y.; Unten, S.; Atsumi, T.; Sakagami, H.; Fujisawa, S. Radical scavenging activity and cytotoxicity of ferulic acid. Anticancer Res. 2002, 22, 2711-2717.

57. Kim, J.K.; Park, S.U. A recent overview on the biological and pharmacological activities of ferulic acid. EXCLI J. 2019, 18, 132-138.

58. Ou, S.; Kwok, K.C. Ferulic acid: Pharmaceutical functions, preparation and applications in foods. J. Sci. Food Agric. 2004, 84, 1261-1269. [CrossRef]

59. Kiliç, I.; Yeşiloğlu, Y. Spectroscopic studies on the antioxidant activity of p-coumaric acid. Biomol. Spectrosc. 2013, 115, 719-724. [CrossRef] [PubMed]

60. Lou, Z.; Wang, H.; Rao, S.; Sun, J.; Ma, C.; Li, J. p-Coumaric acid kills bacteria through dual damage mechanisms. Food Control 2012, 25, 550-554. [CrossRef]

61. Arruda, C.; Ribeiro, V.P.; Mejia, J.A.A.; Almeida, M.O.; Goulart, M.O.; Candido, A.C.B.B.; dos Santos, R.A.; Magalhaes, L.G.; Martins, C.H.G.; Bastos, J.K. Green propolis: Cytotoxic and leishmanicidal activities of artepillin C, p-coumaric acid, and their degradation products. Rev. Bras. Farmacogn. 2020, 30, 169-176. [CrossRef]

62. Itoh, A.; Isoda, K.; Kondoh, M.; Kawase, M.; Watari, A.; Kobayashi, M.; Tamesada, M.; Yagi, K. Hepatoprotective effect of syringic acid and vanillic acid on $\mathrm{CCl}_{4}$-induced liver injury. Biol. Pharm. Bull. 2010, 33, 983-987. [CrossRef] [PubMed]

63. Tai, A.; Sawano, T.; Ito, H. Antioxidative properties of vanillic acid esters in multiple antioxidant assays. Biosci. Biotechnol. Biochem. 2012, 76, 314-318. [CrossRef] [PubMed]

64. Srinivasulu, C.; Ramgopal, M.; Ramanjaneyulu, G.; Anuradha, C.; Kumar, C.S. Syringic acid (SA)—A review of its occurrence, biosynthesis, pharmacological and industrial importance. Biomed. Pharmacother. 2018, 108, 547-557. [CrossRef]

65. Fernández, I.S.; Cuevas, P.; Angulo, J.; López-Navajas, P.; Canales-Mayordomo, Á.; González-Corrochano, R.; Lozano, R.M.; Valverde, S.; Jiménez-Barbero, J.; Romero, A. Gentisic acid, a compound associated with plant defense and a metabolite of aspirin, heads a new class of in vivo fibroblast growth factor inhibitors. J. Biol. Chem. 2010, 285, 11714-11729. [CrossRef] [PubMed]

66. Abedi, F.; Razavi, B.M.; Hosseinzadeh, H. A review on gentisic acid as a plant derived phenolic acid and metabolite of aspirin: Comprehensive pharmacology, toxicology, and some pharmaceutical aspects. Phytother. Res. 2020, 34, 729-741. [CrossRef] [PubMed]

67. Yang, C.S.; Lee, M.-J.; Chen, L. Human salivary tea catechin levels and catechin esterase activities: Implication in human cancer prevention studies. Biomark. Prev. 1999, 8, 83-89.

68. Veluri, R.; Weir, T.L.; Bais, H.P.; Stermitz, F.R.; Vivanco, J.M. Phytotoxic and antimicrobial activities of catechin derivatives. J. Agric. Food Chem. 2004, 52, 1077-1082. [CrossRef] [PubMed] 
69. Venkatakrishnan, K.; Chiu, H.-F.; Cheng, J.-C.; Chang, Y.-H.; Lu, Y.-Y.; Han, Y.-C.; Shen, Y.-C.; Tsai, K.-S.; Wang, C.-K. Comparative studies on the hypolipidemic, antioxidant and hepatoprotective activities of catechin-enriched green and oolong tea in a double-blind clinical trial. Food Funct. 2018, 9, 1205-1213. [CrossRef]

70. Ghayur, M.N.; Khan, H.; Gilani, A.H. Antispasmodic, bronchodilator and vasodilator activities of (+)-catechin, a naturally occurring flavonoid. Arch. Pharm. Res. 2007, 30, 970-975. [CrossRef]

71. Dong, X.; Fu, J.; Yin, X.; Cao, S.; Li, X.; Lin, L.; Huyiligeqi; Ni, J. Emodin: A review of its pharmacology, toxicity and pharmacokinetics. Phytother. Res. 2016, 30, 1207-1218. [CrossRef]

72. Lin, C.-C.; Chang, C.-H.; Yang, J.-J.; Namba, T.; Hattori, M. Hepatoprotective effects of emodin from Ventilago leiocarpa. J. Ethnopharmacol. 1996, 52, 107-111. [CrossRef]

73. Wang, R.; He, R.; Li, Z.; Lin, X.; Wang, L. HPLC-Q-Orbitrap-MS/MS phenolic profiles and biological activities of extracts from roxburgh rose (Rosa roxburghii Tratt.) leaves. Arab. J. Chem. 2021, 14, 103257. [CrossRef]

74. Kedare, S.B.; Singh, R. Genesis and development of DPPH method of antioxidant assay. J. Food Sci. Technol. 2011, 48, 412-422. [CrossRef]

75. Mishra, K.; Ojha, H.; Chaudhury, N.K. Estimation of antiradical properties of antioxidants using DPPH assay: A critical review and results. Food Chem. 2012, 130, 1036-1043. [CrossRef]

76. Abdel-Hameed, E.-S.S. Total phenolic contents and free radical scavenging activity of certain Egyptian Ficus species leaf samples. Food Chem. 2009, 114, 1271-1277. [CrossRef]

77. Perumal Samy, R.; Gopalakrishnakone, P. Therapeutic potential of plants as anti-microbials for drug discovery. Evid. Based Complement. Alternat. Med. 2010, 7, 283-294. [CrossRef] [PubMed]

78. Arif, T.; Bhosale, J.; Kumar, N.; Mandal, T.; Bendre, R.; Lavekar, G.; Dabur, R. Natural products-antifungal agents derived from plants. J. Asian Nat. Prod. Res. 2009, 11, 621-638. [CrossRef]

79. Sher, A. Antimicrobial activity of natural products from medicinal plants. Gomal J. Med. Sci. 2009, 7, 1-17.

80. Ali, H.; Houghton, P.; Soumyanath, A. $\alpha$-Amylase inhibitory activity of some Malaysian plants used to treat diabetes; with particular reference to Phyllanthus amarus. J. Ethnopharmacol. 2006, 107, 449-455. [CrossRef]

81. Ramkumar, K.M.; Thayumanavan, B.; Palvannan, T.; Rajaguru, P. Inhibitory effect of Gymnema montanum leaves on $\alpha$-glucosidase activity and $\alpha$-amylase activity and their relationship with polyphenolic content. Med. Chem. Res. 2010, 19, 948-961. [CrossRef]

82. Mai, T.T.; Thu, N.N.; Tien, P.G.; Van Chuyen, N. Alpha-glucosidase inhibitory and antioxidant activities of Vietnamese edible plants and their relationships with polyphenol contents. J. Nutr. Sci Vitaminol. 2007, 53, 267-276. [CrossRef] [PubMed]

83. Benalla, W.; Bellahcen, S.; Bnouham, M. Antidiabetic medicinal plants as a source of alpha glucosidase inhibitors. Curr. Diabetes Rev. 2010, 6, 247-254. [CrossRef]

84. Derosa, G.; Maffioli, P. $\alpha$-Glucosidase inhibitors and their use in clinical practice. Arch. Med. Sci. AMS 2012, 8, 899-906. [CrossRef] [PubMed]

85. Jo, S.; Ka, E.; Lee, H. Comparison of antioxidant potential and rat intestinal $\alpha$-glucosidases inhibitory activities of quercetin, rutin, and isoquercetin. Int. J. Appl. Res. Nat. Prod. 2009, 2, 52-60.

86. Elya, B.; Handayani, R.; Sauriasari, R.; Hasyyati, U.S.; Permana, I.T.; Permatasari, Y.I. Antidiabetic activity and phytochemical screening of extracts from Indonesian plants by inhibition of alpha amylase, alpha glucosidase and dipeptidyl peptidase IV. Pak. J. Biol. Sci. 2015, 18, 279. [CrossRef]

87. Sarah, Q.S.; Anny, F.C.; Mir, M. Brine shrimp lethality assay. Bangladesh J. Pharmacol. 2017, 12, 186-189. [CrossRef]

88. Raghavendra, H.; Prashith, K.T.; Valleesha, N.; Sudharshan, S.; Chinmaya, A. Screening for cytotoxic activity of methanol extract of Putranjiva roxburghii Wall (Euphorbiaceae) seeds. Pharmacogn. J. 2010, 2, 335-337. [CrossRef]

89. Fabbro, D.; Ruetz, S.; Buchdunger, E.; Cowan-Jacob, S.W.; Fendrich, G.; Liebetanz, J.; Mestan, J.; O’Reilly, T.; Traxler, P.; Chaudhuri, B. Protein kinases as targets for anticancer agents: From inhibitors to useful drugs. Pharmacol. Ther. 2002, 93, 79-98. [CrossRef]

90. Kaur, P.; Mehta, R.G.; Singh, B.; Arora, S. Development of aqueous-based multi-herbal combination using principal component analysis and its functional significance in HepG2 cells. BMC Complement. Altern. Med. 2019, 19, 1-17. [CrossRef]

91. Balkrishna, A.; Sharma, V.K.; Das, S.K.; Mishra, N.; Bisht, L.; Joshi, A.; Sharma, N. Characterization and anti-cancerous effect of Putranjiva roxburghii seed extract mediated silver nanoparticles on human colon (HCT-116), pancreatic (PANC-1) and breast (MDA-MB 231) cancer cell lines: A comparative study. Int. J. Nanomed. 2020, 15, 573. [CrossRef] [PubMed]

92. Zandi, K.; Ahmadzadeh, S.; Tajbakhsh, S.; Rastian, Z.; Yousefi, F.; Farshadpour, F.; Sartavi, K. Anticancer activity of Sargassum oligocystum water extract against human cancer cell lines. Eur. Rev. Med. Pharmacol. Sci. 2010, 14, 669-673. [PubMed] 